NBER WORKING PAPER SERIES

\title{
WHEN UNCLE SAM INTRODUCED MAIN STREET TO WALL STREET: LIBERTY BONDS AND THE TRANSFORMATION OF AMERICAN FINANCE
}

\author{
Eric Hilt \\ Matthew S. Jaremski \\ Wendy Rahn \\ Working Paper 27703 \\ http://www.nber.org/papers/w27703 \\ NATIONAL BUREAU OF ECONOMIC RESEARCH \\ 1050 Massachusetts Avenue \\ Cambridge, MA 02138 \\ August 2020, Revised July 2021
}

The views expressed herein are those of the authors and do not necessarily reflect the views of the National Bureau of Economic Research.

NBER working papers are circulated for discussion and comment purposes. They have not been peer-reviewed or been subject to the review by the NBER Board of Directors that accompanies official NBER publications.

(C) 2020 by Eric Hilt, Matthew S. Jaremski, and Wendy Rahn. All rights reserved. Short sections of text, not to exceed two paragraphs, may be quoted without explicit permission provided that full credit, including $\odot$ notice, is given to the source. 
When Uncle Sam Introduced Main Street to Wall Street: Liberty Bonds and the Transformation of American Finance

Eric Hilt, Matthew S. Jaremski, and Wendy Rahn

NBER Working Paper No. 27703

August 2020, Revised July 2021

JEL No. N12,N22,N42

\begin{abstract}
We study the effects of the liberty bond drives of World War I on financial intermediation in the 1920s and beyond. Using panel data on U.S. counties, and an instrument that captures differences in the approaches used to market the bonds, we find that higher liberty bond subscription rates led to an increase in investment banks and a contraction in commercial bank assets. We also find that in the late 1930s, individuals residing in states where liberty bond subscription rates had been higher were more likely to report owning stocks or bonds. Although they were conducted to support the American effort in World War I, the liberty loan drives reshaped American finance.
\end{abstract}

Eric Hilt

Wellesley College

Department of Economics

106 Central Street

Wellesley, MA 02481

and NBER

ehilt@wellesley.edu

Matthew S. Jaremski

Utah State University

Department of Economics and Finance

3565 Old Main Hill

Logan, UT 84322

and NBER

matthew.jaremski@usu.edu
Wendy Rahn

University of Minnesota

1414 Social Science

267 19th Ave. South,

Minneapolis, MN 55455

wrahn@polisci.umn.edu 


\section{Introduction}

The first three decades of the twentieth century witnessed a transformation of American financial markets. Whereas commercial bank loans had long been the dominant instrument through which financial intermediation occurred in the United States, during the 1920s securities markets became increasingly important. This growth in securities markets was accompanied by an expansion in the number of American investment banks, which totaled more than 6,000 in 1929 and competed aggressively with commercial banks for the savings of businesses and households. The expansion of securities markets was also accompanied by an even more substantial expansion of securities ownership; the total number of individuals owning corporate stock in the United States grew from less than one million in 1910 to more than 10 million by the early 1930 s. ${ }^{1}$ Financial historians have long suggested that the liberty loan drives of World War I played an important role in these changes, but the lack of disaggregated data has prevented direct tests of their effect. Using unique county-level data, we provide the first empirical analysis of this hypothesis.

The liberty loan drives enlisted millions of volunteer salespeople, as well as the entire commercial and investment banking industries, and were supported by massive propaganda campaigns, rallies led by movie stars, and door-to-door solicitations. By any standard, the campaigns' efforts were successful: at least 23 million Americans subscribed to the bonds, and in doing so, most of them were introduced to security ownership for the first time. The experience of owning liberty bonds may then have made middle-income households more interested in investing in other securities. The investment banking industry gained valuable experience as well: by participating in the campaigns, they learned how to market financial assets to middle-income households - and that the savings of those households represented a potentially enormous market. In the era before the rise of institutionally managed retirement accounts and mutual funds, tapping into the savings of middle-income families meant marketing securities to them directly. In the 1920s, investment banks began to do exactly that, by opening new retail-oriented offices, and promoting securities using new methods such as print advertising campaigns and sponsored radio programing. The consequences were far-reaching; as William Z. Ripley's (1927: vi-vii) Main Street and Wall Street argued, "without the Liberty Loan campaigns leading to the great increase of popular investment," the rise of "very widely held" corporations in the 1920s would not have occurred on the same scale.

\footnotetext{
${ }^{1}$ No comprehensive data on corporate shareholding exist for this period, and definitive counts of total numbers of U.S. shareholders should be treated with skepticism, as they are generally unsubstantiated. Several scholars, including Warshow (1924), Means (1930), Berle and Means (1932), and Bernheim and Schneider (1935), have produced reasonable estimates of the total number of shareholdings from samples of public corporations. Rutterford and Sotiroupolos (2017: 500) use such data to estimate that there were 0.81 million shareholders in 1907 , and 10 to 12 million in 1932 .
} 
Arguments such as these have been repeated frequently in the literature, but no study to our knowledge has empirically analyzed the effects of liberty bonds on American financial development. Typically, such claims are backed by little more than references to aggregate data or scattered anecdotal evidence. A careful empirical analysis, however, is important because a number of other factors also likely contributed to the deepening of financial markets and the expansion of shareholding during the 1920s. According to Means (1930: 591), tax policies introduced during World War I drove firms that had previously relied on wealthy investors to search out "persons of moderate means." And as Nicholas (2008) notes, a number of public companies in the 1920s produced new revolutionary consumer goods such as radios, mechanical refrigerators, and nylon. It would not be unreasonable to imagine that the securities of those corporations may have been particularly attractive to ordinary households. To the taxation and technology-driven explanations, one might add another one based purely on returns. O'Sullivan (2016) argues that the war effort provided a stimulus to manufacturing companies, producing rapid growth and strong dividends in the 1920s. And then beginning around 1927, the entire stock market offered extraordinary returns, potentially drawing in many new investors (Galbraith 1954; Nicholas 2008; White 1990). In order to assess the role that the liberty bond drives played in the changes in American financial markets, one must isolate their effects from such other factors.

This paper provides a quantitative analysis of the role of the liberty loan drives in the transformation of American finance in the 1920s and beyond. We use annual panel data on U.S. counties from 1910 to 1929 to analyze the effects of the liberty bonds on the commercial and investment banking industries. We also use household survey data from the 1930s to study the effect of the loan drives on securities ownership over the longer run. The liberty loan drives provided a bundle of different treatments simultaneously: financial literacy education, encouragements to save and invest, sales campaigns extolling the benefits of bond ownership, credit for bond purchases, and, ultimately, experience with investing. Our analysis cannot distinguish among these different treatments' effects, and instead will quantify the impact of all of them together. Our analysis can, however, isolate the effects of the bond drives from those of other changes that would have been felt nationally, such as new tax policies, the proliferation of listed high-tech firms, and the strong returns offered by the stock market.

We begin by focusing on the timing of changes in financial markets, by estimating annual differences in differences with our county data. The results indicate that higher liberty bond subscription rates were associated with a relative contraction in the growth of commercial banks, and an expansion of investment banks across counties in the years after the liberty bond campaigns, in models with county, year, and Federal Reserve District-by-year fixed effects. The estimated annual 
effects show clearly that these changes were not the product of ongoing trends, but instead began at the end of the loan drives and continued through the 1920s. Consistent with stronger competition between the two types of institutions, we also find that the estimated effect of the presence of investment banks on the assets of commercial banks in the same county became significantly negative after the liberty loan campaigns.

Those results are suggestive but they may not have a causal interpretation, because demand for liberty bonds may have been correlated with unobservable county characteristics - the income or financial sophistication of the population, for example - that could have influenced financial development differentially in the 1920s. We therefore instrument for liberty bond subscription rates using a supply-side factor. Whereas in most counties the bonds were marketed by different volunteer groups whose efforts were not always well coordinated, in a handful of states a different approach was used, which was known as the allotment system. The allotment system, which we describe in detail below, made subscribing the default option for all property owners, so that not subscribing often involved an opt-out process. It was also a more centralized approach to marketing the bonds, which may have made it more effective for other reasons. But importantly, the decision to adopt it was not made at the local level in response to financial conditions, but rather was made at the state or Federal Reserve District level, and imposed on counties within their borders. The use of the allotment system therefore created a source of variation in liberty bond subscriptions that was not driven by local demand-side factors. We use two different IV specifications that leverage the allotment system in slightly different ways, and both clearly confirm that the liberty bonds led to a substantial relative contraction in commercial banks and expansion of investment banks after 1918. Our IV estimates are generally precise enough to be informative, with weak instrument robust confidence intervals that usually exclude zero. A one-standard-deviation increase in the liberty bond participation rate in a county led to a relative decrease of commercial bank assets of about 20 percent, and an increase in the number of investment banks of about 5 percent.

We then use data from the late 1930s, obtained from the earliest household surveys that asked about securities ownership, to analyze the effects of the liberty loan campaigns on the rates at which households owned stocks and bonds. The survey instrument only recorded the state of residence of respondents, limiting our analysis to the effects of state-level variation in liberty bond subscriptions. We use both of our IV specifications with these data, and the estimates indicate that individuals residing in states with higher liberty bond subscription rates were significantly more likely to report owning stocks and bonds in the 1930s, even conditional on a range of household characteristics. This result is consistent with other work that has shown that financial experience can have long-run effects on individuals' asset allocations (e.g., Malmendier and Nagel, 2011). 
More broadly, the results of this paper confirm the importance of financial literacy and trust for participation in financial markets. The liberty bond drives can be thought of as massive interventions aimed in part at shaping households' attitudes toward investing in securities and providing information that increased financial literacy. Households were presented with messages indicating that investing in government bonds was appropriate not just for speculators, but for all citizens (Ott, 2011). The campaigns enlisted women and children, and trained them as sales agents with materials that included basic facts about bonds as well as the principles of interest calculation. Studies of modern data have shown that financial knowledge reduces barriers to investing in the stock market (Haliassos and Bertaut, 1995; Vissing-Jorgensen, 2004; Van Rooij, Lusardi, and Alessie, 2011) as does trust (Guiso, Sapienza and Zingales, 2008). We advance those literatures by analyzing the effects of a historical campaign that provided financial knowledge and sought to increase trust in financial markets. The liberty loan campaigns also encouraged thrift and offered households an easily accessible savings vehicle, which modern studies have shown can have substantial effects among the poor (Dupas and Robinson, 2013; Kast and Pomerantz, 2014; Bachas et al., 2018; Dupas et al., 2018).

Our analysis also contributes to the literature on competition between commercial banks and financial markets (Allen and Gale, 1997; Song and Thakor, 2010). Studies of modern data have found that increases in the level of households' participation in the stock market reduce the demand for bank deposits, and that this decline in deposits reduces the availability of bank loans (Lin, 2020). We show that this effect occurred on a large scale in the 1920s, as households became more interested in participating in securities markets after being exposed to the liberty loan campaigns. The resulting decline in commercial bank assets likely led to a decrease in local bank lending, which previous scholarship using historical data has found to have significant effects (e.g., Jaremski, 2014; Fulford, 2015; Rajan and Ramcharan, 2015, 2016; Carlson, Correia and Luck, 2020).

Our results also contribute to the literature on the participation of ordinary households in securities markets in the 1920s (e.g., Warshaw, 1924; Means, 1930; Edwards, 1938; Haven, 1940; Friend et al., 1958, 1967; Calomiris, 1995, 2002; Baskin and Miranti, 1997; Calomiris and Raff, 1995; Mitchell, 2007; O'Sullivan, 2007, 2016; Ott, 2011; Rutterford and Sotiropoulos, 2017; and Calomiris and $\mathrm{Oh}, 2018$ ). Several of these works have argued that the liberty loan campaigns created the preconditions for the proliferation of securities ownership over subsequent years. We advance this literature by giving empirical content to this hypothesis, and distinguishing the effects of the loan campaigns from other explanations of the changes that occurred in the 1920s. We also go well beyond the arguments of those works, and explore the effects of the loan drives on the commercial banking system, and on the growth and competitiveness of investment banks. 


\section{The Liberty Loan Campaigns}

The American effort in World War I led to a 25-fold increase in federal government expenditures. Treasury Secretary McAdoo decided to fund most of the cost of the war with borrowing (see Garbade, 2012; Kang and Rockoff, 2015; Sutch, 2015; and Hall and Sargent, 2019). In addition to reducing the burdens of taxation, McAdoo believed that borrowing offered another advantage: selling government bonds to the public would give ordinary Americans a financial stake in the war effort. McAdoo (1931: 378) even likened the bond sales campaigns to a military operation, arguing that those "who could not serve in the trenches in France might nevertheless serve in the financial trenches at home."

In total, the liberty loans raised about $\$ 22$ billion for the federal government, equivalent to more than $\$ 5$ trillion today as a constant share of GDP. Rather than selling bonds continuously, the Treasury held four distinct bond drives from May 1917 through October 1918, and an additional victory loan drive conducted following the end of the war in April and May 1919. The Treasury delegated management of the loan drives to the Federal Reserve Banks, whose liberty loan committees then created sub-committees to head the sales effort in particular states, which in turn selected countyand city-level organizations. Essentially all of civil society was enlisted by these committees, and diverse groups such as fraternal societies, religious organizations, the boy scouts, and women's clubs contributed to the effort. The design of the bond issues and the fulfillment of subscriptions reflected the goal of attracting as many subscribers as possible. The bonds were sold with par values as low as $\$ 50$, and subscriptions could be fulfilled through installment plans. In addition, all of the issues were oversubscribed, and the Treasury weighted allocations toward small investors.

A summary of the different loan drives is presented in Table 1. The Treasury collected separate totals for the subscribers of each issue, but did not attempt to determine the number of households or individuals who subscribed to at least one liberty bond. The number of subscribers to the largest loan, the fourth-22.8 million - therefore represents the minimum possible number of total liberty loan subscribers, and the true total was likely higher. This represented a substantial portion of the adult population (there were about 66.4 million individuals aged 18 or older in 1920), and the rate was even higher when considering the proportion of households that purchased a bond. A survey by the Bureau of Labor Statistics in 1918-19 found that nearly 70 percent of urban, middle-income households had subscribed to a liberty bond within the past year (authors' calculations from data in Olney 1995). Given how uncommon the ownership of financial assets was before the war, it is quite likely that for most subscribers, their liberty bonds were the first financial assets other than a checking or savings bank account that they had ever owned. 
Financial institutions were enthusiastic participants in the liberty loan drives, and their efforts were critical to the campaigns' success. Yet the loan drives had many significant short- and long-term consequences for those institutions.

Commercial banks benefitted in the short run, and likely suffered in the longer run. Subscriptions to the loans could only be submitted through one of those institutions, and the funds received for subscriptions were typically left on deposit until needed by the Treasury. The Treasury and Fed quickly learned that it was necessary to permit subscribers to buy the bonds on credit to raise the required sums, and in response, the "borrow and buy" program was created, which operated through commercial banks and created a new line of business for them. The Federal Reserve banks rediscounted loans with liberty bonds as collateral at favorable rates, making them attractive for commercial banks.

Yet these lending opportunities were abruptly curtailed by the Federal Reserve in the post-war years. The expansion of Federal Reserve credit through rediscounts contributed significantly to the increase of the money supply during the war years, and in the spring of 1920, total indebtedness of member banks to the Federal Reserve was $\$ 2.5$ billion, an unprecedented amount regarded as alarming by Fed officials (Wicker, 1966). In an effort to induce a period of contraction and deflation, the Federal Reserve Banks raised their discount rates substantially in 1919 and 1920 (Friedman and Schwartz, 1963). This resulted in a significant contraction in member bank borrowing from the Federal Reserve.

With investment banks, the effects of the liberty loan drives were likely the opposite. The Treasury did not pay commissions on the sales of liberty bonds, even though investment banks devoted considerable time and resources to the sales effort. Prominent investment banks also stopped marketing some of their regular securities in order to encourage more people to purchase liberty bonds. But in spite of these short-term costs, many investment bankers perceived that the industry would benefit in the longer run. Charles Mitchell, the President of National City Company, wrote of "the development of a large, new army of investors in this country, who have never heretofore known what it means to own a coupon bond and who may in the future be developed into savers and bond buyers" (Mitchell, 1917: 296).

The investment banking industry responded by adopting new business methods. Prior to WWI, the securities underwriting business had been dominated by a small number of conservative private banks that marketed new issues primarily to the wealthy, and to institutions such as insurance companies and large commercial banks. In the 1920s, a new generation of investment banking firms acquired a growing share of the market in part by promoting securities to the 'army' of small investors that the liberty bonds had created. Several of these firms were led by bankers who had been involved 
in the loan campaigns, and employed some of the same techniques used to promote the liberty bonds, such as partial payment plans for securities purchases, print and radio advertising, and the creation of departments that specialized in selling securities to women or immigrants (Carosso, 1970: 236, 260; Peach, 1941: 33; Quinn, 2019: 114).

With the substantial expansion of the investment banking industry in the 1920s and growing interest in securities markets, many households and institutions allocated a smaller proportion of their savings to deposit accounts at commercial banks in order to invest in bonds or stocks. Commercial bankers had anticipated this consequence of the liberty loan drives, and expressed apprehension that "the drawing of so many millions out of the banks would reduce their deposits and diminish their resources..." (Daniels, 1918: 335). Competition between securities markets and commercial banks was not new, but was limited in part by the small share of households participating in securities markets. By drawing more individuals into the securities market, the liberty loan drives likely intensified this competition.

Figure 1 presents data on the commercial banking sector, at the top, and on the investment banking sector, at the bottom, for the country as a whole, during the 1910-29 period. The number of commercial banks in the United States rose gradually from 1910-1921, and that growth rate generally did not accelerate during the period of the liberty loan drives. Then after peaking in 1921, the total number of commercial banks gradually began to fall, as declines in commodities prices led to significant exit and consolidation in the commercial banking sector in rural areas in the 1920s (see Jaremski and Wheelock, 2020). The growth of the total assets of the commercial banking sector per county (in red) clearly accelerated during the liberty loan drives, but this was followed by a significant contraction in 1921, likely in response to the Federal Reserve's policy changes intended to curtail rediscounts. After that decline, bank assets rebounded and continued to expand over the rest of the decade, although at a slower pace than during the war years. The size of the commercial banking sector as a whole clearly grew throughout our period of study, but the aggregate data could mask differential changes across banks and locations.

Among investment banks, at bottom, the patterns were different. In a reflection of the relative lack of barriers to entry in that industry, the total number of those institutions (in blue) was much more volatile. It grew from 1914 - the first year for which data are available - to 1918, and then collapsed in 1919. The rapid drop in 1919 may indicate that the war years and commission-free liberty loan drives were quite disruptive to that industry. The number of investment banks bounced back in 1920, and then remained high throughout the rest of the 1920s, with a small decline occurring in 1923 . The red line, which presents the number of counties with at least one investment bank, shows relatively stable growth up to 1919, and then a large, discrete increase from 1919 to 1920 . The year 1920 saw not only 
a large increase in the number of investment banks, but a 60 percent increase in the number of counties in which investment banks were present, reflecting a significant expansion in the industry's geographical reach which persisted throughout the 1920s.

These aggregate data suggest that the liberty loan drives may have had a strong influence on American financial development. Yet other factors that were not directly related to the liberty bond drives may also have contributed to those changes. For example, Figure 2 presents monthly data for an index of share prices from Shiller (2000) in red, and also the volume of shares traded on the NYSE, in blue, for 1910-29. These data clearly show the rising equity values and trading volumes over the 1920s, which accelerated dramatically around 1927. The extraordinary returns offered in the stock market produced something of a mania for stocks, which Galbraith famously described as a "speculative orgy" (1954:11). It is almost certainly the case that this episode attracted many households into the stock market, created new opportunities for investment banks, and drew resources out of deposit accounts at commercial banks.

In what follows, we will attempt to distinguish the effects of the liberty bond drives from the effects of rising share prices and other changes that would have been felt nationally, by focusing on the relationship between liberty bond subscription rates in particular places and changes in financial development in those places.

\section{Data}

To study the effect of the liberty bond drives on the financial system, we assemble data on subscription rates in the loan drives, on commercial banks, and on investment banks, all at the county level. Our liberty bond subscription data were collected from pamphlets published by the Federal Reserve Banks' liberty loan committees, as described in Hilt and Rahn (2020). Those sources reported total numbers of subscribers by county, and following Hilt and Rahn, we calculate subscription rates by dividing those totals by county populations as reported in the 1920 census. Our primary measure of liberty bond subscriptions is for the Fourth Liberty Loan, the largest issue, and the one for which there were data for the greatest number of counties. Not every Federal Reserve district published countylevel subscription data, however, so our measure of loan subscriptions is only available for the Richmond, Cleveland, St Louis, Minnesota, and San Francisco Federal Reserve districts plus the state of Iowa. In some of the analysis that follows, we also study the effects of subscriptions to the third loan, and of the increases from the third to the fourth using the smaller subset of data that is available for both the third and fourth loan. Figure 3 presents a map of our county subscription rate data and 
illustrates that our sources cover at least some counties from every census division except New England.

Our commercial bank data consist of annual county-level balance sheet information from 1910 to 1929. The data were obtained from Annual Report of the Comptroller of the Currency and reports published by each state's banking departments. The Comptroller published balance sheets for every national bank annually, but many states did not publish balance sheets for their state-chartered banks and trust companies (see Mitchener and Jaremski, 2015). Our data include the counties of every state for which (1) data on state-chartered banks were published throughout the period and (2) liberty bond subscription data were available. These restrictions create a sample of 869 counties in 17 states. $^{2}$

Our investment bank data come from Investment Banks and Brokers of America, a directory of investment banks in the United States published beginning in 1914. This appears to be the most comprehensive source available for these firms during the period under study, and claimed to list all the "firms, individuals and banks that do an active investment business." Its entries include many partnerships, corporations, and a small number of individuals, some of which operated as branches of firms from other cities. We designate each listing in the directory as an investment bank. As these firms were not required to publicly report information on their balance sheets or customer accounts, the information in the directory enables us only to observe the number of investment banks in a county-year and their names, and little else. We digitized the data for 1914, 1916, 1918, 1919, 1920, 1922, 1923, 1925, and 1929 which are the only editions we have been able to find through the Library of Congress and other archives and libraries across the world.

We utilize county-level census information from Haines (2004). ${ }^{3}$ These data enable us to control for various county characteristics that may have influenced both liberty bond subscriptions and changes in the structure of a county's financial services industry. These include measures of the size of the market, such as total population and urbanization, as well as the composition of the market such as the fraction of the population that was non-white and the number of farms in the county. When combined with annual crop prices from Carter et al. (2006), these data also allow us to control for the run up in agricultural prices during World War I and the collapse of those prices after the war.

\footnotetext{
${ }^{2}$ These states are: Iowa, Idaho, Illinois, Maryland, Michigan, Missouri, Mississippi, Montana, North Carolina, Ohio, Oregon, South Carolina, South Dakota, Virginia, Washington, Wisconsin, and West Virginia. For Michigan and Wisconsin, we only have data for the counties in the Minneapolis (Ninth) Fed District, and for Illinois, we only have data for the counties in the St Louis (Eighth) Fed District. Because most states provide a consolidated report for banks with branches, we drop California because the massive branching that occurred during the 1920s would throw off the county-level statistics. For the few gaps in reporting, we fill the missing values using a linear interpolation so as to obtain a balanced panel. We also drop the few observations for counties where no commercial banks were present.

${ }^{3}$ We aggregate counties to their 1910 boundaries so as to have consistent county definitions over time. Values between census years are linearly interpolated.
} 
Following Jaremski and Wheelock (2020), a crop price index is calculated as the value of a basket of the county's crops at market prices in a given year normalized by the value of that same basket of crops at their pre-war prices, where the fixed basket is defined by the county-specific crop output shares in 1910 .

Summary data for our sample counties are presented in Table 2. On average the liberty bond subscription rate for the fourth loan was equivalent to 16.5 percent of the county population, and the standard deviation of the subscription rate was 10 percent. In columns (2) and (3) in the table, we compare characteristics between counties with above- and below-median subscription rates.

Unsurprisingly, those with higher subscription rates were more urban, more educated, had more immigrants, were less agricultural, had larger commercial banking sectors, and were more likely to have an investment bank. We address these differences by including these county characteristics as time-varying controls in our regressions, by controlling for time-invariant county fixed effects, and with the use of an instrument.

Finally, we obtain household-level data on securities ownership in the 1930s from surveys conducted by the Gallup organization. George Gallup conducted five polls in 1937 and 1938 that included the question: "Do you happen to own any stocks or bonds at this time?" (Gallup, 1937, 1938). In order to achieve sufficient samples for some of the smaller US states, we pooled the five polls, resulting in a combined sample size of 14,805 respondents. These polls were not based on random samples, but instead quota-controlled samples in which interviewers were instructed to target a predetermined number of respondents from particular segments of society. Political scientists Adam Berinksy and Eric Schickler have produced weights for these polls that compensate for the deficiencies in their sampling methods, which we use in all of our analysis of this data (Berinsky, 2006; Berinsky and Schickler, 2011).

\section{Annual Difference in Differences: The Timing of Liberty Bond Effects}

In order to identify the contribution of the liberty bond campaigns to changes in financial markets, we next turn to our county-level data. We begin with annual difference-in-differences models that focus on the timing of the changes associated with the liberty bond campaigns for both commercial and investment banks.

If the liberty bond campaigns led households to reallocate a share of their savings into investments in securities such as stocks and bonds, then the commercial banking sector should have grown more slowly than it would have in the absence of those campaigns and the investment banking sector should have grown more quickly. We therefore focus on commercial bank outcomes related to 
the banks' size and the behavior of depositors: total assets and total deposits. Because data on investment banks' assets or accounts were not reported to any state or federal regulators, we must limit our analysis to the number of investment banks within counties and an indicator for the presence of at least one investment bank, which captures the geographic extent of the industry.

For both sets of outcomes, we focus on interactions between county liberty bond subscription rates and year-fixed effects, in the context of a model with county fixed effects and standard errors clustered by county. The interactions provide a test of whether higher liberty bond subscription areas were different than low liberty bond subscription areas in a given year, compared with the excluded year. Patterns in the annual coefficients over time will reveal whether any effects we observe represented the continuation of an ongoing trend, or whether they emerged in the period during or after the liberty loan drives.

Table 2 revealed some differences between counties with high liberty bond take-up rates, compared to those where the rate was lower. We thus include a number of time-varying county characteristics as controls. ${ }^{4}$ The model we estimate is:

$$
\text { Outcome }_{c, t}=a+\beta_{t} \text { Liberty }_{c} \times \text { Year }_{t}+\theta X_{c, t}+\lambda_{t} \text { FedDistrict }_{c} \times \text { Year }_{t}+\gamma_{c}+e_{c, t},
$$

where Outcome $c, t$ is either the logarithm of total commercial bank assets, the logarithm of total commercial bank deposits, the logarithm of investment banks, or an indicator for the presence of any investment banks for county $c$ in year $t$; Liberty $c$ is the subscription rate for the fourth liberty loan of county $c$, in percentage points; the $Y_{e a r}$ variables are indicators for each sample year; $X_{c, t}$ is a vector of time-varying county characteristics; FedDistrict ${ }_{c}$ is a set of indicator variables for the Fed districts; $\gamma_{c}$ is a vector of county-fixed effects; and $e_{c, t}$ is the error term, clustered by county.

The estimated $\beta_{t}$ coefficients for the commercial bank outcomes of equation (1) are presented in Figure 4, which plots the point estimates and two-standard-error bands relative to the excluded year of 1910. In the top panel for log total assets of commercial banks, the figure reveals that counties with high liberty bond subscription rates experienced a significant relative decline in commercial bank assets during and after the liberty bond drives. A ten percentage point (about a 1 standard deviation) increase in liberty bond subscriptions led to an 8.2 percent decrease in commercial bank assets by 1920

\footnotetext{
${ }^{4}$ These include the logarithm of population, the logarithm of the number of farms, the fraction of the population living in a location over 2,500 people, an indicator for whether the county contained a city of 25,000 people or more, the fraction of the population that was non-white, the fraction of the population that was born in Germany, the fraction of the population that was an immigrant from a country other than Germany, the fraction of the population that was illiterate, and the crop price index. We also include an indicator for the presence of a Federal Reserve Bank or Branch and interact it with the year-fixed effects, to account for the differential effect the presence that those institutions may have had over time.
} 
and an 11.6 percent decrease by 1929, relative to other counties. Further evidence consistent with our interpretation of these effects is presented in the bottom panel of Figure 4. A necessary implication of the mechanism we propose to explain these changes is that commercial bank deposits should have increased relatively more slowly in areas with high liberty bond take-up rates. In the figure, the effect on deposits is quite similar to the effect on bank assets.

Recalling Figure 1, these effects actually work against the overall positive trend in bank assets during the period. Perhaps just as importantly, we find no difference in commercial bank assets or deposits across locations related to the liberty bond subscription rates before the drives took place. The lack of any pre-1917 effect confirms that areas with high liberty bond subscription rates were not evolving along substantially different trends relative to areas with low liberty bond subscription prior to the campaigns.

The timing of the changes exhibited in the figure helps rule out the concern that the decline in commercial bank activity we attribute to the liberty bonds was instead due to the post-war decline in production and prices in agricultural areas. The significant decline in commercial bank activity in counties with high liberty bond subscription rates between 1917 and 1919 moves against the substantial increase in crop prices and incomes through 1919 that expanded bank balance sheets (Jaremski and Wheelock, 2020). Combined with the lack of an effect before 1917, the timing strongly indicates that the effect on commercial banks was driven by the liberty loan campaigns, rather than the economic slowdown after the war. Of course, it is possible that other unobserved factors may have contributed to these changes; in Section 5 we address such concerns using instrumental variables specifications.

The estimates of the $\beta_{t}$ coefficients for the investment bank outcomes from equation (1) are presented in Figure 5, which plots the point estimates and two-standard-error bars by year, relative to the excluded year of 1914, the first year of the data. These estimates reflect the irregular pattern of the available years of the source data. The top panel of the figure shows the effects on the log number of investment banks, and the lower panel shows the effects on the presence of at least one investment bank. Reassuringly, there was no ongoing differential growth of investment banks in the counties with high liberty bond subscription rates up to 1918. But then beginning in 1919 and especially in 1920, there was a positive effect on the number of investment banks. The effect then grew in size 1922 as the industry expanded (see Figure 1), and then persisted at a lower level throughout the rest of the 1920s. The results in the bottom panel of Figure 5 for the investment bank indicator outcome are similar, suggesting the liberty bond drives helped push investment banks into new areas.

These estimates also help rule out the concern that the relative decline in commercial bank activity in counties with high liberty bond subscription rates after 1917 was due to a general 
contraction in financial markets or the post-war slump in agricultural areas. Instead, the negative effect we document among commercial banks was isolated to that class of institutions. Investment banks expanded in the same counties where commercial banks grew more slowly, and one would not expect that to have been the case if economic conditions were deteriorating.

We next look for evidence in support of stronger competition between investment banks and commercial banks. We take two approaches. The first simply examines whether the association between the presence of an investment bank and the assets of local commercial banks became more negative after the liberty bond drives. The second focuses only on counties where an investment bank entered during or immediately following the liberty bond drive years (1916-1920); these investment banks were most likely induced to enter by the liberty bond drives. For the second approach, we construct an indicator variable for counties gaining an investment bank during that period and, similar to the first approach, we investigate whether those counties experienced differential growth of commercial bank assets after 1920, and whether they were already seeing declines prior to World War I.

The first model, in which the investment bank indicator can vary over time, takes the form:

$$
\text { Assets }_{c, t}=a+\beta_{t} \mathbb{1}(\text { InvBanks }>0)_{c, t} \times \text { Year }_{t}+\theta X_{c, t}+\lambda_{t} \text { FedDistrict }_{c} \times \text { Year }_{t}+\gamma_{c}+e_{c, t}
$$

where $\mathbb{1}(\text { InvBanks }>0)_{c, t}$ is an indicator variable that takes a value of 1 if county $c$ had at least one investment bank in year $t$ and the rest of the variables retain their definitions. We focus on commercial bank assets as the results are very similar to those for deposits.

The estimates of equation (2) are presented in the top panel of Figure 6 . The coefficient on investment banks is positive before 1918, it begins to decline in 1918 and becomes significantly negative by 1920 and remains so for the rest of the 1920s. A county that had an investment bank would have had 10.4\% more commercial bank assets in 1916, but $7.0 \%$ and $7.7 \%$ less commercial banks assets in 1920 and 1925, respectively. This suggests that the competitive relationship between investment banks and commercial banks changed with the liberty bond drives.

The second model, which focuses on counties that gained an investment bank 1916-1920 is:

$$
\text { Assets }_{c, t}=a+\beta_{t} \mathbb{1}\left(\triangle \text { InvBanks }_{1916-20}>0\right)_{c} \times \text { Year }_{t}+\theta X_{c, t}+\lambda_{t} \text { FedDistrict }_{c} \times \text { Year }_{t}+\gamma_{c}+e_{c, t},(3)
$$

where $\mathbb{1}\left(\triangle \text { InvBanks }_{1916-20}>0\right)_{c}$ is an indicator variable that takes a value of 1 if the county gained at least one investment bank between 1916 and 1920 and the rest of the variables retain their definitions from equation (2). 
The lower panel of Figure 6 presents the point estimates of $\beta_{t}$ for Equation (3). These results are similar but larger than those in the upper panel. Counties that gained an investment bank during the liberty bond drives had only mild differences in commercial bank assets prior to 1917 , and the difference becomes consistently negative and declined steeply during the years of the liberty loan drives. A county that gained at least one investment bank is expected to have had an insignificant 5.8\% less commercial bank assets in 1916, but a significant $18.7 \%$ and $20.7 \%$ less commercial banks assets in 1920 and 1925 respectively, relative to 1910. These results suggest that competition between investment banks and commercial banks became considerably stronger during the liberty bond drives rather than before the war (i.e., 1910-1913) or during the early parts of the war (i.e., 1914-1915).

\section{Main Results: Instrumental Variables Specifications}

The previous results have shown that counties where the fourth liberty loan participation rate was higher experienced a sudden and sustained decline in commercial bank balance sheets and an increase in investment banks after 1918, in the context of models that control for a wide variety of county characteristics and geographic factors. Nevertheless, it is possible that the demand for liberty bonds may have been correlated with unobservable county characteristics that influenced financial development differentially in the 1920s. For example, the incomes, risk preferences, or financial sophistication of households may have contributed to their willingness to purchase liberty bonds, and also attracted investment banks into the county in subsequent years. To address this concern, we instrument for liberty bond subscriptions using an administrative system that was adopted by some states' liberty loan committees, generally known as the allotment system.

With the allotment system, counties were divided into small districts, and the leaders of local liberty loan committees used property tax records to assign a subscription quota to every household. The committee then communicated those quotas directly to the households, in letters that informed them that they were expected to report to their local subscription office at the beginning of the campaign to subscribe. The loan drives began with the usual rallies and parades, and were supplemented with the usual advertising and publicity, with volunteer groups giving speeches and promoting the bonds. But the process of collecting subscriptions was completely centralized, and for the most part only households that failed to subscribe were visited by representatives of the liberty loan committee.

The allotment system was intended to "overcome the indifference" of rural areas to the loan campaigns (Holbrook and Appel, 1932: 203). It was developed during the second loan in a handful of 
communities in Minnesota, and its effectiveness convinced the leadership of the Liberty Loan Committee for the Minneapolis (Ninth) Fed District to order that it be utilized throughout the District for the third and subsequent loans (Ninth District Liberty Loan Committee 1918, vol. 1 no. 1, p. 3; Holbrook and Appel, 1932, ch. 8). Just over Minnesota's southern border, it was also adopted by the state of Iowa for the third and subsequent loans (Whitney, 1923). When used widely, it was found to produce "remarkably effective results" (Kinyon, 1918: 16); the governor of Minnesota stated that "the allotment plan was largely responsible for the splendid showing made by our state" in the third loan (Ninth District Liberty Loan Committee 1918, vol. 2 no. 2, p. 3). The system then spread to neighboring states for the fourth loan: the other states besides Iowa in the Chicago (Seventh) Fed District adopted it, as did the state of Idaho. Figure 7 presents a map showing the states that used the allotment system. ${ }^{5}$

An important reason behind the effectiveness of the system is that it compelled local loan committees to assemble lists of all potential subscribers, and to collect all subscriptions directly, which enabled them to identify and follow up with non-subscribers. This meant committees could try to increase subscription rates in a targeted way, which would have been particularly valuable in areas where promoting the bonds was difficult.

Evidence of this is presented in Figure 8, which plots the distribution of participation rates for the fourth loan for counties utilizing the allotment system, at left, and counties in bordering states that did not use it, at right. The upper tails of the distributions were relatively similar, indicating that the allotment system likely had little effect in areas with high take-up rates. ${ }^{6}$ In contrast, the lower tails of the distributions were quite different; very few allotment system counties' subscription rates were below the median level (18.4 percent) for the border states and many were tightly clustered just above that level. One must interpret this purely cross-sectional comparison with caution, but if the distribution for the neighboring counties can be taken as an approximate counterfactual for the distribution of allotment counties, the figure suggests that the allotment system raised subscription rates the most in counties where take up would have been quite low, which was likely true of sparsely populated rural areas. In such places, "enormous distances and poor transportation facilities" hampered the campaigns, making the advantages of the allotment system especially valuable (U.S. Treasury, 1918: 10).

\footnotetext{
${ }^{5}$ In some cases, slightly different versions of the system were adopted; some counties apparently centralized subscription taking without initially mailing quotas to all households, calling their system the "voluntary system." See Seventh Federal Reserve District (1918: vol.1 no. 9, p. 1). We code the counties of the state as having used the allotment system if contemporary sources indicated that some version of the system was used.

${ }^{6}$ The 90th percentile of subscription rates for the allotment counties was 32 percent, whereas for the counties in bordering states it was 30 percent.
} 
Importantly, the allotment system was imposed on local loan committees by the state and Federal Reserve District committees that oversaw them; the decision to adopt it was not made at the local level in response to financial conditions. For example, publications from the Minneapolis Fed reported that the District's leadership was "insistent upon its being put into effect everywhere," and conducted an extensive campaign to train and educate local committees on how to implement the system (Ninth District Liberty Loan Committee 1918, vol. 1 no. 1, p. 3). The validity of the allotment system as an instrument therefore hinges on whether the states that adopted it were the same as other states in ways that affected subsequent financial development, or if they were evolving along parallel trends, which are requirements of the independence assumption.

In Table 3A we show that the characteristics of states that adopted the allotment system were not systematically different. There were some minor differences, however; consistent with the allotment system being used to improve the effectiveness of the campaigns in sparsely populated rural areas, the states that adopted it had lower populations and more farms, and the joint F-tests for some of the regressions are significant at the 10 percent level. We control for all the social characteristics in the table in our regressions, so the validity of the instrument hinges on the allotment system being independent of counties' subsequent financial development conditional on these controls. In the Appendix, we show that when we drop rural areas, our IV results do not change, which suggests that our results are not driven by the more rural character of the allotment states. ${ }^{7}$

Reassuringly, in Table 3B we show that the use of the allotment system does not predict changes in our county-level outcome variables during the period prior to the loan campaigns. The one exception (column (2)) is that the allotment system states had been experiencing contractions in their investment banking industries in the years leading up to the bond drives; this trend is in the opposite direction of the expected effect of the allotment system. The Appendix presents annual differences in differences of the effect of the allotment system on our outcomes; although the estimates are quite noisy, there is no evidence of any effect prior to the loan drives.

Our main IV specification, estimated via 2SLS, is as follows:

$$
\begin{aligned}
\text { Outcome }_{c, t} & =a+\beta \text { Liberty }_{c} \times{\text { post } 18_{t}+\theta X_{c, t}+\gamma_{c}+e_{c, t}} \\
\text { Liberty }_{c} \times{\text { post } 18_{t}} & =a+\pi \text { Allotment }_{c} \times{\text { post } 18_{t}+\xi X_{c, t}+\gamma_{c}+u_{c, t}}
\end{aligned}
$$

\footnotetext{
${ }^{7}$ Another concern might be that the 1918 influenza outbreak, which interrupted the fourth loan drive (see Hilt and Rahn, 2018), was less severe in allotment states. For the states within our sample, the allotment states had influenza death rates of 4.43 per thousand, whereas the non-allotment states have a death rate of 4.0 per thousand (cacluations from data in Bureau of the Census, 1920).
} 
where the second-stage regression at top is essentially the same as Equation (1) above, only with a post-1918 indicator replacing the year interactions. In the first-stage regression below it, the liberty bond subscription rate interacted with a post-1918 indicator is regressed on an indicator for the allotment system interacted with post-1918, as well as county fixed effects and the same time-varying county characteristics as in the second stage. Because the use of the allotment system was strongly correlated with Federal Reserve districts, we do not include district-by-year fixed effects, and because the choice to adopt the allotment system was often made at the state level, we cluster the standard errors by state. ${ }^{8}$

Table 4 presents the estimates of $\beta$ and $\pi$ for the four different outcomes: log commercial bank assets, log commercial bank deposits, log number of investment banks, and an indicator for the presence of an investment bank. The first-stage regressions, presented in the lower panel of the table, show a strong, positive effect of the allotment system on participation rates that ranges between 8 and 9 percentage points, relative to a mean rate of about 16.5 percent. We report two different tests for weak instruments, the Kleibergen-Paap F-statistic and the effective F-statistic due to Montiel Olea and Pfluger (2013). These are all above 10, and Andrews, Stock and Sun (2019) have shown that when the effective F-statistic is greater than 10, conventional t-statistics perform quite well. Yet to be conservative, we also report weak-instrument robust 95 percent confidence sets for our estimates.

The IV estimates for the effect of liberty bond subscriptions, presented in the upper part of the table, are economically significant and relatively similar in magnitude to the OLS estimates. ${ }^{9}$ The estimates imply that a one-standard-deviation increase in liberty bond subscription rates (10.2 percent) led to a decrease in log commercial bank assets of 0.21 , an increase in the log number of investment banks of 0.05 , and an increase in the rate at which investment banks were present in a county of about $3 \%$ in the post-1918 period. With the exception of the log investment banks outcome (which has a pvalue of 0.18 ), these results are also statistically significant. However, the weak IV robust confidence sets for both investment bank outcomes do include 0 .

A natural question that arises with these results is whether the effects of liberty bond subscriptions obtained by the allotment system instrument are externally valid. Our IV estimates are identified from increases in subscription rates that would not have occurred if the allotment system had not been put in place. Recalling Figure 8, these were in counties that in the absence of the allotment system would have had low subscription rates, which were likely sparsely populated rural areas. Yet in

\footnotetext{
${ }^{8}$ We lack county-level liberty bond or investment bank data for some of the states that used the allotment system; the states in our dataset that used the system are Idaho, Iowa, Michigan, Montana, South Dakota, and Wisconsin.

${ }^{9}$ As weak instruments tend to bias estimates toward OLS, any remaining concerns with this issue would imply that our results understate the true causal effects, since the IV estimates are larger than the OLS estimates.
} 
the Appendix, we show that when we drop purely rural counties, defined as those lacking an urban center of at least 2,500 people, the magnitudes of the estimated coefficients remain mostly unchanged. We conclude that the degree of heterogeneity of the effects of liberty bonds was limited.

To rule out any remaining concerns regarding weak instruments, we next present an alternative IV specification that leverages the allotment system in a different way. We first decompose the subscription rate for the fourth liberty loan into the subscription rate for the third loan, and the increase from the third to the fourth. The fourth loan was much larger than the third with higher participation rates; the mean subscription rate for the third loan was 13.8 percent and the mean increase in participation from the third to the fourth was 3.3 percent. ${ }^{10}$ The higher subscription rates for the fourth loan were produced by the greater efforts exerted in marketing the bonds. Conditional on the third loan subscription rate, which reflects factors like income and financial sophistication, the increase from the third to the fourth was more directly a function of the efforts utilized in marketing the fourth. For the states that adopted the allotment system for the first time with the fourth liberty loan, the increase in subscription rates was likely to be much greater. We therefore instrument for the increase from the third loan to the fourth using an indicator for the switch to the allotment system, and identify the effects of liberty bond participation by focusing on this component of the fourth loan subscription rate.

The regressions are as follows:

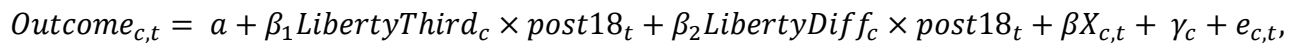

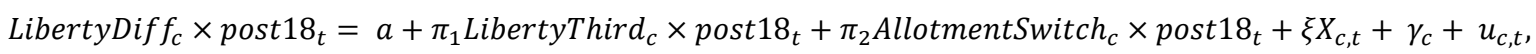

where LibertyThird ${ }_{c}$ is the county subscription rate to the third liberty loan, LibertyDiff $f_{c}$ is the difference between the fourth loan subscription rate and third, and AllotmentSwitch is $_{c}$ an indicator for counties that switched to the allotment system for the fourth loan.

An important limitation of this specification is that although four states switched to the allotment system for the fourth loan, county-level liberty bond and banking data are available for only one of them, Idaho. ${ }^{11}$ We can only estimate the effect of the change to the allotment system, and therefore the increase in liberty bond participation for the fourth loan, from comparisons between Idaho and other states. Reassuringly, however, in the Appendix, we show that qualitatively similar results are obtained by restricting the sample to Idaho and states that border it, indicating that the

\footnotetext{
${ }^{10}$ Summary statistics for the third loan subscription rate and increase from the third to the fourth are presented in the Appendix. The difference in the number of counties between the $3^{\text {rd }}$ and $4^{\text {th }}$ loans is the result of the St Louis (Eighth) Fed District not reporting data for the $3{ }^{\text {rd }}$ loan.

${ }^{11}$ The counties of the Chicago Fed District in Illinois, Indiana, Michigan, and Wisconsin adopted the system for the fourth loan as well, but that district did not report county-level liberty bond data.
} 
results are unlikely to be the product of regional differences in the increase in subscriptions between the third and fourth loans.

The estimates of Equation (5) are presented in Table 5, with the first stage coefficients in the lower panel. In both the first stage and second stage, we control for the subscription rate for the third loan, but we only report the estimate for the second stage, as it is of independent interest. With this specification, the first stage is much stronger, and the effective F-statistics range from 37.9 to 41.7 , well above the threshold of 23.1 proposed by Montiel Olea and Pfluger (2013). ${ }^{12}$ The IV estimates of the effect of the increase in liberty bond subscription rates are all statistically significant, and the weak IV robust confidence sets all exclude zero. The IV estimates imply that a one-standard-deviation increase in the change in subscription rates from the third loan to the fourth (6.54 percent) led to a decrease in log commercial bank assets of 0.32 , an increase in the log number investment banks of 0.07 , and an increase in the likelihood that an investment bank was present in the county of about 4 percent. These effects are similar to but larger than those obtained from our main IV specification, indicating that the liberty bonds had a stronger influence on Idaho's subsequent development than on the other states that used the allotment system.

Overall, these results are consistent with the notion that the liberty loan campaigns changed American households' attitudes towards investing, and that investment banks sought to capitalize on the new opportunities for their industry by moving into counties where subscription rates had been high.

\section{Determinants of Individuals' Ownership of Financial Assets, 1930s: State-level Data}

We next investigate the longer-run effects of the liberty bonds on securities ownership. The earliest available sources that record whether or not households owned financial assets are surveys conducted by Gallup in the mid-1930s. We use these surveys to determine whether the ownership rates of financial assets were higher in places where liberty bond subscription rates had been higher, conditional on individual survey respondents' characteristics such as occupation, age, race and whether or not they lived in a small town or on a farm. As we observe financial asset ownership nearly 20 years after the liberty bond drives, this analysis will reveal whether the many different mechanisms through which liberty bonds may have led to greater levels of security ownership had persistent effects. Yet the limitations of the data will prevent us from being able to distinguish among those different potential mechanisms or show when the change in behavior occurred.

\footnotetext{
${ }^{12}$ Montiel Olea and Pfluger's (2013) tests for bias of 10\% with significance levels of 5\% are rejected when the effective $\mathrm{F}$ is greater than 23.1 ; they propose this threshold as an "asymptotically valid rule of thumb."
} 
The geographical identifiers in the data report only the state in which the respondent resided. The surveys did retain information on whether or not the respondent resided in a large city or a small town, but not the identity of the city or town. We are therefore unable to utilize the variation across counties within states in liberty bond subscription rates, and instead focus on state-level liberty bond subscription rates, as reported by the U.S. Treasury (1920).

Figure 9 presents a scatterplot of the state-level stock ownership rates as calculated from the Gallup surveys against the state-level liberty bond subscription rates, with the marker sizes proportional to state populations. There is a clear positive relationship; in the 1930s, households residing in states where participation rates in the liberty loan drives had been higher were more likely to own financial assets. The relationship is also clearly not driven by particular states such as New York, which were likely to have had higher levels of financial asset ownership both before and after the liberty loan drives.

We next explore whether this relationship is robust to controlling for the characteristics of individual survey respondents, and to the use of our IV specifications. We estimate the following models:

$$
\text { FinAsset }_{i, s, j}=a+\beta_{1} \text { Liberty }_{s}+\beta_{2} Z_{i}+\delta_{j}+e_{i, s, j}
$$

and

$$
\text { FinAsset }_{i, s, j}=a+\beta_{1} \text { LibertyThird }_{s}+\beta_{2} \text { LibertyDiff }_{s}+\beta_{3} Z_{i}+\delta_{j}+e_{i, s, j}
$$

where FinAsset $_{i s j}$ is an indicator variable equal to one if survey respondent $i$ residing in state $s$

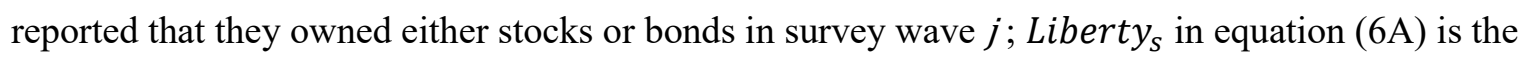
subscription rate for the fourth liberty loan for the state in which the survey respondent resided; LibertyThird $_{s}$ and LibertyDiff $f_{s}$ in equation (6B) are the subscriptions rate for the third loan and the increase in subscription rates from the third to the fourth in the state in which respondent $i$ resided; $\delta_{j}$ are fixed effects for each of the five survey waves; and $Z_{i}$ is a vector of characteristics of respondent $i$ such as age, gender, race, proxies for income, and locational characteristics. The error term $e_{i, s, j}$ is clustered by state. We estimate both equations using linear probability models, and as with our previous results, we also estimate IV specifications using the allotment system or the switch to the allotment system as instruments for the liberty bond subscription rate or the increase in the rate from the third to the fourth loan. 
The estimates, presented in Table 6, imply that liberty loan subscription rates were strong predictors of later financial asset ownership, even conditional on a broad range of individual characteristics. In column (1), we estimate Equation (6A) using OLS, and in column (2) we instrument for the state's liberty loan subscription rate using an indicator for the use of the allotment system, which produces a very similar point estimate. In columns (4) and (5) we estimate Equation (6B), with the third loan and the increase between the third and the fourth. Both have strong positive estimates, and when we instrument for the increase from the third to the fourth using an indicator for the change to the allotment system, the point estimate again remains similar to the OLS value. With these results, the effective F-statistics are below 10, making the weak IV robust confidence sets particularly important. For the specification in column (2), the interval excludes 0, whereas the one in column (4) does not, meaning that the latter results should be interpreted cautiously.

These results suggest that the liberty loan drives had significant and lasting effects. The estimate in column (2) implies that a one standard deviation increase in state liberty loan subscription rate ( 8.3 percent) led to a 3.3 percent increase in the rate at which households owned stocks. A potential source of concern regarding this result could be that, since they only represent cross-sectional differences 20 years after the liberty loans, any estimated effect of liberty bonds on securities ownership rates in 1930s may simply be a consequence of persistent differences across states that were correlated with liberty bond subscription rates. Yet our use of an instrument helps address this concern. So long as the choice of the allotment system was not itself associated with persistent differences (other than through the use of liberty bonds), we can conclude that the variation in liberty bond subscriptions created by its use caused stock ownership to be higher in the 1930s.

\section{Conclusion}

This paper analyzes the effects of the liberty loan campaigns of World War I, and provides a quantitative assessment of their role in reshaping American finance. During the 1920s, American securities markets expanded, as the investment banking industry grew, securities ownership proliferated, and the commercial banking industry declined in relative terms. Financial historians have long argued that the liberty bond drives contributed to these changes, but their effects have never been analyzed systematically.

Using unique county level data, we find that that higher liberty bond subscription rates led to an increase in the number of investment banks, a contraction in commercial bank assets and a stronger competitive effect of investment banks on commercial banks. We also find that individuals residing in states with higher liberty bond subscription rates were more likely to own financial assets such as 
stocks and bonds in the mid-1930s. Similar to other examples of how wars contributed to the financial development of nations (e.g., Saint-Paul, 1996; Dickson, 1967; Sylla, 2002; Thomson, 2016), the results of this paper suggest that the American effort in World War I introduced millions of households to bond ownership, and in doing so, contributed to the expansion of securities investing in the 1920s that likely helped fuel the large-scale expansion in American industry of the mid-twentieth century.

Many other factors contributed to the changes in American financial markets that occurred in the 1920s. And given the low rates of securities ownership among households in the United States in 1910, the focus of the investment banking industry on wealthy individuals and institutions would almost certainly have changed in the absence of the liberty loan campaigns during the prosperous 1920s. Yet our estimates imply that the contribution of the liberty loans was significant. One must be cautious in inferring total effects from estimates of relative changes, but our results imply that in the absence of the liberty loans, there would have been about 8.25 percent fewer investment banks in 1929 , and commercial bank assets would have been 24 to 41 percent greater in the $1920 \mathrm{~s} .{ }^{13}$ In the 1930 s, the stock ownership rate among households would have been about 8.9 percentage points lower. We cannot assess the overall welfare effects of these changes, as they likely influenced access to external finance among large firms, household savings rates and portfolio allocations, and local access to bank credit. But it is clear that the liberty bonds reshaped American financial markets.

Although they were conducted to raise funds and generate political support for the war effort, the liberty loan drives also led to a significant shift in financial intermediation. By introducing millions of households to bond ownership, they contributed to the expansion of the investment banking industry and securities investing in the 1920s that remained defining characteristics of American financial markets throughout the rest of the twentieth century.

\section{References}

Allen, F., Gale, D. 1997. Financial Markets, Intermediaries and Intertemporal Smoothing. Journal of Political Economy 105(3): 523-546.

Andrews, I. 2018. Valid Two-Step Identification-Robust Confidence Sets for GMM. Review of Economics and Statistics 100(2): 337-348.

Andrews, I., Stock, J., Sun, L. 2019. Weak Instruments in Instrumental Variables Regression: Theory and Practice. Annual Review of Economics 11:727-53.

\footnotetext{
${ }^{13}$ Calculated as $e^{(\widehat{\beta} \times \bar{x})}-1$, where $\hat{\beta}$ is the estimate of the effect of the liberty bond subscription rate on the $\log$ value of the financial outcome, and $\bar{x}$ is the mean subscription rate in the county dataset. For the commercial bank asset outcome, we report the value using both the OLS and the IV estimate; for the investment bank outcome, those values are the same.
} 
Bachas, P., Gertler, P., Higgins, S., Siera, E. 2018. Digital financial services go a long way: Transactions costs and financial inclusion. AEA Papers and Proceedings 108: 444-448.

Baskin, J., Miranti, P. 1997. A History of Corporate Finance. Cambridge: Cambridge University Press. Berle, A., Means, G. 1932. The Modern Corporation and Private Property. New York: Macmillan. Berinsky, A. 2006. American Public Opinion in the 1930s and 1940s: The Analysis of QuotaControlled Sample Survey Data. Public Opinion Quarterly 70(4):499-529.

Berinsky, A., Schickler, E. 2011. The American Mass Public in the 1930s and 1940s [Computer file]. Individual surveys conducted by the Gallup Organization [producers], 1936-945: Roper Center for Public Opinion Research, University of Connecticut [distributor], 2011.

Bernheim, A., and Schneider, M., eds. 1935. The Securities Markets. New York: Twentieth Century Fund.

Bureau of the Census, U.S. Department of Commerce. 1920. Mortality Statistics 1918: Nineteenth Annual Report. Washington: Government Printing Office.

Brown, J. D., and Earle, J. 2017. Finance and growth at the firm level: Evidence from SBA loans. Journal of Finance 72: 1039-1080.

Calomiris, C. 1995. The Costs of Rejecting Universal Banking: American Finance in the German Mirror, 1870-1914, in The Coordination of Economic Activity Within and Between Firms, N. Lamoreaux and D. Raff, eds., 257-312. Chicago: University of Chicago Press.

Calomiris, C. 2002. Banking and Financial Intermediation, in Technological Innovation and Economic Performance, Benn Steil, David G. Victor, and Richard R. Nelson, eds., 285-313. Princeton: Princeton University Press.

Calomiris, C., Oh, E. 2018. Who Owned Citibank? Familiarity Bias and Business Network Influences on Stock Purchases, 1925-1929. NBER Working paper No. w24431.

Calomiris, C., and Raff, D. 1995. The Evolution of Market Structure, Information, and Spreads in American Investment Banking, in Anglo-American Finance: Financial Markets and Institutions in 20th-Century North America and the U.K. R. Sylla and M. Bordo, eds., 103160. Business One Irwin.

Carlson, M., Correia, S., Luck, S. 2020. The Effects of Banking Competition on Growth and Financial Stability: Evidence from the National Banking Era. Working Paper, Federal Reserve.

Carosso, V. 1970. Investment Banking in America: A History. Cambridge: Harvard University Press.

Carter, S., Gartner, S., Haines, M., Olmstead, A., Sutch, R., Wright, G. 2006. Historical Statistics of the United States, Millennial Edition. New York: Cambridge.

Daniels, J. 1918. Address by Secretary Daniels, in Proceedings of the Forty-Fourth Convention of the American Bankers Association. New York: Fred E. Farnsworth.

Dickson, P.G.M. 1967. The Financial Revolution in England: A Study in the Development of Public Credit, 1688-1756. New York: St. Martin's Press.

Dupas, P., Robinson, J. 2013. Why Don't the Poor Save More? Evidence from Health Savings Experiments. American Economic Review 103(4): 1138-1171.

Dupas, P., Karlan, D., Robinson, J., Ubfal, D. 2018. Banking the Unbanked? Evidence from three countries. AEJ: Applied Economics 10(2): 257-97.

Edwards, G. 1938. The Evolution of Finance Capitalism. New York: Longmans Green \& Co.

Federal Reserve Board. 1919. Fifth Annual Report of the Federal Reserve Board. Washington: Government Printing Office.

Friedman, M., Schwartz, A. 1963. A Monetary History of the United States, 1867-1960. Princeton: Princeton University Press.

Friend, I., Hoffman, G.W., Winn, W., Hamburg, M., Schor, S. 1958. The Over-the-Counter Securities Markets. New York: McGraw Hill.

Friend, I., Longstreet, J., Mendelson, M., Miller, E., Hess, A.P. Jr. 1967. Investment Banking and the New Issues Market. New York: World Publishing.

Fulford, S. 2015. How Important are Banks for Economic Development? National Banks in the United States, 1870-1900. Review of Economics and Statistics 97(5): 921-38. 
Garbade, K. 2012. Birth of a Market: The U.S. Treasury Securities Market from the Great War to the Great Depression. Cambridge, Mass: MIT Press.

Gallup Organization. 1937-38. Gallup Polls 1937-0086, 1937-0099, 1938-0110, 1938-0127, 1938-

0128. https://doi.roper.center/?doi=10.25940/ROPER-31087070, 31087083, 31087094, $31087111,31087112$.

Galbraith, J. K. 1954. The Great Crash: 1929. New York: Houghton Mifflin.

Guiso, L., Sapienza, P., Zingales, L. 2008. Trusting the Stock Market. Journal of Finance 63(6): 25572600.

Haines, M. 2004. Historical, Demographic, Economic, and Social Data: The United States, 1790-2000. ICPSR Study 2896. Ann Arbor, MI: Inter-university Consortium for Political and Social Research.

Haliassos, M., and Bertaut, C. 1995. Why do so few hold stocks? Economic Journal 105.432: 11101129.

Hall, G., Sargent, T. 2019. Complications for the United States from International Credits: 1913-1940, in Dabla-Norris, ed., Debt and Entanglements Between the Wars. Washington, DC: International Monetary Fund.

Haven, T. K. 1940. Investment Banking under the Securities and Exchange Commission. Ann Arbor: University of Michigan.

Hilt, E., Rahn, W. 2020. Financial Asset Ownership and Political Partisanship: Liberty Bonds and Republican Electoral Success in the 1920s. Journal of Economic History, 80(3): 746-81.

Holbrook, F., Appel, L. 1932. Minnesota in the War With Germany, vol. 2. St Paul: Minnesota Historical Society.

Jaremski, M. 2014. National Banking's Role in U.S. Industrialization, 1850-1900. Journal of Economic History 74:109-140.

Jaremski, M., Wheelock, D. Forthcoming. Banking on the Boom, Tripped by the Bust: Banks and the World War I Agricultural Price Shock. Journal of Money, Credit, and Banking.

Jayaratne, J., Strahan, P. 1996. The finance-growth nexus: Evidence from bank branch deregulation. Quarterly Journal of Economics 111: 639-670.

Kang, S.W., Rockoff, H. 2015. Capitalizing Patriotism: The Liberty Bonds of World War I. Financial History Review 22: 45-78.

Kast, F., Pomeranz, D. 2014. Saving more to borrow less: Experimental evidence from access to formal savings accounts in Chile. NBER Working Paper Series, number 20239.

Kinyon, G. 1918. A Fair-Play Plan That Sold the Bonds. Bankers Monthly 35(6): 16-17.

Lin, L. 2020. Bank Deposits and the Stock Market. Review of Financial Studies 33: 2622-2658.

Malmendier, U., Nagel, S. 2011. Depression Babies: Do Macroeconomic Experiences Affect RiskTaking? Quarterly Journal of Economics 126(1): 373-416.

McAdoo, W. 1931. Crowded Years: The Reminiscences of William G. McAdoo. Boston: Houghton Mifflin Company.

Means, G. 1930. The Diffusion of Stock Ownership in the United States, Quarterly Journal of Economics 44: 561-600.

Meeker, J.E. 1930. The Work of the Stock Exchange. New York: Ronald Press.

Michell, C. 1917. Sound Inflation. Magazine of Wall Street, 20(5), 9 June, 295-6.

Mitchell, L. 2007. The Speculation Economy: How Finance Triumphed Over Industry. San Francisco: Berrett-Koehler.

Mitchener, K., Jaremski, M. 2015. The Evolution of Bank Supervisory Institutions: Evidence from American States. Journal of Economic History 75: 819-859.

Montiel Olea, J.L., Pflueger, C. 2013. A Robust Test for Weak Instruments. Journal of Business and Economic Statistics 31(3): 358-369.

National Woman's Liberty Loan Committee. 1918. Report of National Woman's Liberty Loan Committee for $4^{\text {th }}$ Liberty Loan. Washington: Government Printing Office. 
Nicholas, T. 2008. Does Innovation Cause Stock Market Runups? Evidence from the Great Crash. American Economic Review, 98(4): 1370-96.

Ninth Federal Reserve District Liberty Loan Committee. 1918. The Liberty Bell (various issues).

Olney, M. 1995. Saving and Dissaving of 12,817 American Households, 1917-1919. Amherst, MA:

Martha L. Olney, University of Massachusetts [producer], 1993. Ann Arbor, MI: Interuniversity Consortium for Political and Social Research [distributor]. http://doi.org/10.3886/ICPSR06276.v1

O'Sullivan, M. 2007. The Expansion of the U.S. Stock Market, 1885-1930: Historical Facts and Theoretical Fashions. Enterprise and Society 8(3): 489-542.

O'Sullivan, M. 2016. Dividends of Development: Securities Markets in the History of US Capitalism, 1866-1922. New York: Oxford University Press.

Ott, J. 2011. When Wall Street Met Main Street: The Quest for an Investors' Democracy. Cambridge, Mass.: Harvard University Press.

Peach, W. N. 1941. The Securities Affiliates of National Banks. Baltimore: Johns Hopkins.

Quinn, S. 2019. American Bonds: How Credit Markets Shaped a Nation. Princeton: Princeton University Press.

Rajan, R., Ramcharan, R. 2015. The Anatomy of a Credit Crisis: The Boom and Bust in Farm Land Prices in the United States in the 1920s. American Economic Review 105: 1439-77.

Rajan, R., Ramcharan, R. 2016. Local Financial Capacity and Asset Values: Evidence from Bank Failures. Journal of Financial Economics 120: 229-251.

Ripley, W. Z. 1927. Main Street and Wall Street. Boston, Little, Brown, and Company.

Rutterford, J., Sotiropoulos, D. 2017. The Rise of the Small Investor in the United States and United Kingdom, 1895 to 1970. Enterprise and Society 18(3): 485-535.

Saint-Paul, G. 1996. Demand-Driven Financial Development, in Hermes and Lensink, eds., Financial Development and Economic Growth. London: Routledge.

Seventh Federal Reserve District Liberty Loan Committee. 1918. The War Loan Reveille (various issues).

Shiller, R. 2000. Irrational Exuberance. Princeton, New Jersey, Princeton University.

Song, F., Thakor, A. 2010. Financial System Architecture and the Co-Evolution of Banks and Capital Markets. Economic Journal, 120 (547): 1021-1055.

Sutch, R. 2015. Financing the Great War. A Class Tax for the Wealthy, Liberty Bonds for All. BEHL working paper no. 2015-09.

Sylla, R. 2002. Financial Systems and Economic Modernization. Journal of Economic History 62(2): 277-292.

Thomson, D. 2016. Like a Cord through the Whole Country: Union Bonds and Financial Mobilization for Victory. Journal of the Civil War Era 6(3): 347-75.

United States Treasury. 1918. Report of National Woman's Liberty Loan Committee for the Fourth Liberty Loan Campaign. Washington: Government Printing Office.

United States Treasury. 1920. Annual Report of the Secretary of the Treasury on the State of the Finances for the Fiscal Year Ended June 30, 1919. Washington: Government Printing Office.

Van Rooij, M., Lusardi, A., Alessie, R. 2011. Financial literacy and stock market participation. Journal of Financial Economics 101: 449-472.

Vissing-Jorgensen, A. 2004. Perspectives on behavioral finance: Does irrationality disappear with wealth? Evidence from expectations and actions. In M. Gertler and K. Rogoff (eds.), NBER Macroeconomics Annual 2003, Cambridge, MIT Press.

Warshow, H.T. 1924. The Distribution of Corporate Ownership in the United States, Quarterly Journal of Economics 39: 15-38.

Whitney, N. 1923. The Sale of War Bonds in Iowa. Iowa City: State Historical Society.

Wicker, E. 1966. A reconsideration of Federal Reserve policy during the 1920-1921 depression. Journal of Economic History 26.2: 223-238. 
White, E. 1990. The Stock Market Boom and Crash of 1929 Revisited. Journal of Economic Perspectives, 4(2): 67-83. 


\section{FIGURES AND TABLES}

\section{Table 1:}

\section{Liberty Loan Characteristics and Subscriptions, by Loan}

This table presents summary descriptive information for each of the five liberty bond issues. All liberty bonds were issued at par, so their yield to maturity at issue was equal to their coupon rate. The first and second loans could be converted into subsequent loans bearing higher coupon rates. The dual coupon rates for the victory loans reflected the fact that investors could choose whether or not their bonds were tax free; tax free bonds paid the lower rate. Sources: Annual Reports, U.S. Treasury; Garbade (2012).

\begin{tabular}{|c|c|c|c|c|c|}
\hline & First & Second & Third & Fourth & Victory \\
\hline \multirow[t]{2}{*}{ Subscription Period } & May-Jun & Oct & Apr-May & Sept-Oct & Apr-May \\
\hline & 1917 & 1917 & 1918 & 1918 & 1919 \\
\hline Coupon Rate & $3.50 \%$ & $4.00 \%$ & $4.25 \%$ & $4.25 \%$ & $3.75 \%$ or $4.75 \%$ \\
\hline Maturity, in Years & 30 & 25 & 10 & 20 & 4 \\
\hline Total Subscriptions, in Billions (\$) & 2.000 & 3.809 & 4.177 & 6.959 & 4.500 \\
\hline Number of Subscribers, in Millions & 4 & 9.4 & 18.4 & 22.8 & 11.8 \\
\hline
\end{tabular}


Table 2:

\section{County Characteristics in 1910}

This table presents means and standard deviations [in brackets] of the characteristics of the sample counties. There are 858 total counties in the sample in 1910. The number of investment banks is measured in 1914 because that is the first year for which data are available. Column (1) presents data for all counties, column (2) for counties with above-median subscription rates, and column (3) for counties with below-median rates. For definitions and sources, see text.

\begin{tabular}{|c|c|c|c|}
\hline & $\begin{array}{c}\text { All } \\
\text { Counties }\end{array}$ & $\begin{array}{l}\text { Above- } \\
\text { Median } \\
\text { Liberty } \\
\text { Bonds } \\
\end{array}$ & $\begin{array}{c}\text { Below } \\
\text { Median } \\
\text { Liberty } \\
\text { Bonds } \\
\end{array}$ \\
\hline & (1) & $(2)$ & $(3)$ \\
\hline Liberty Bond $4^{\text {th }}$ Loan Subscription Rate, in Percentage Points & $\begin{array}{c}16.534 \\
{[10.228]}\end{array}$ & $\begin{array}{l}25.172 \\
{[6.388]}\end{array}$ & $\begin{array}{c}7.895 \\
{[4.364]}\end{array}$ \\
\hline Ln(Population) in County in 1910 & $\begin{array}{c}9.867 \\
{[0.728]}\end{array}$ & $\begin{array}{c}9.872 \\
{[0.882]}\end{array}$ & $\begin{array}{c}9.862 \\
{[0.535]}\end{array}$ \\
\hline Fraction of County Population that was Non-White in 1910 & $\begin{array}{c}0.138 \\
{[0.211]}\end{array}$ & $\begin{array}{c}0.038 \\
{[0.097]}\end{array}$ & $\begin{array}{c}0.239 \\
{[0.244]}\end{array}$ \\
\hline Fraction of County Population that was German Immigrant in 1910 & $\begin{array}{c}0.017 \\
{[0.023]}\end{array}$ & $\begin{array}{c}0.029 \\
{[0.025]}\end{array}$ & $\begin{array}{c}0.006 \\
{[0.014]}\end{array}$ \\
\hline Fraction of County Population that was Other Immigrant in 1910 & $\begin{array}{c}0.057 \\
{[0.079]}\end{array}$ & $\begin{array}{c}0.097 \\
{[0.085]}\end{array}$ & $\begin{array}{c}0.016 \\
{[0.043]}\end{array}$ \\
\hline Fraction of County Population that was Illiterate in 1910 & $\begin{array}{c}0.088 \\
{[0.087]}\end{array}$ & $\begin{array}{c}0.033 \\
{[0.039]}\end{array}$ & $\begin{array}{c}0.142 \\
{[0.088]}\end{array}$ \\
\hline Fraction of County Population that was Urban in 1910 & $\begin{array}{c}0.161 \\
{[0.214]}\end{array}$ & $\begin{array}{c}0.240 \\
{[0.250]}\end{array}$ & $\begin{array}{c}0.082 \\
{[0.129]}\end{array}$ \\
\hline Indicator for City with 25,000 People Present in County & $\begin{array}{c}0.051 \\
{[0.221]}\end{array}$ & $\begin{array}{c}0.096 \\
{[0.294]}\end{array}$ & $\begin{array}{c}0.007 \\
{[0.083]}\end{array}$ \\
\hline Ln(Number of Farms) in County in 1910 & $\begin{array}{c}7.555 \\
{[0.689]}\end{array}$ & $\begin{array}{c}7.404 \\
{[0.711]}\end{array}$ & $\begin{array}{c}7.706 \\
{[0.630]}\end{array}$ \\
\hline Federal Reserve Bank or Branch in County by 1920 & $\begin{array}{c}0.009 \\
{[0.096]}\end{array}$ & $\begin{array}{c}0.019 \\
{[0.135]}\end{array}$ & $\begin{array}{c}0 \\
{[0]}\end{array}$ \\
\hline Ln(Total Commercial Bank Assets) in County in 1910 & $\begin{array}{l}14.135 \\
{[1.347]}\end{array}$ & $\begin{array}{l}14.761 \\
{[1.230]}\end{array}$ & $\begin{array}{l}13.509 \\
{[1.155]}\end{array}$ \\
\hline Ln(Total Commercial Bank Deposits) in County in 1910 & $\begin{array}{c}13.833 \\
{[1.362]}\end{array}$ & $\begin{array}{l}14.494 \\
{[1.238]}\end{array}$ & $\begin{array}{c}13.172 \\
{[1.142]}\end{array}$ \\
\hline Number of Commercial Banks in County in 1910 & $\begin{array}{c}7.711 \\
{[6.487]}\end{array}$ & $\begin{array}{c}10.422 \\
{[7.349]}\end{array}$ & $\begin{array}{c}5.000 \\
{[3.940]}\end{array}$ \\
\hline Number of Investment Banks in County in 1914 & $\begin{array}{c}0.394 \\
{[4.299]}\end{array}$ & $\begin{array}{c}0.757 \\
{[6.059]}\end{array}$ & $\begin{array}{c}0.021 \\
{[0.159]}\end{array}$ \\
\hline
\end{tabular}


Table 3A:

Determinants of the Adoption of the Allotment System Across States

This table presents OLS estimates of linear probability models with state-level data where the dependent variable is an indicator for the use of the allotment system in the fourth loan. The allotment system was a centralized administrative system used in some states' liberty loan drives. There were 48 U.S. states at the time. Robust standard errors in parentheses below the coefficients. * denotes significance at $10 \%$; ** at $5 \%$ level and $* * *$ at $1 \%$ levels.

\begin{tabular}{|c|c|c|c|}
\hline & \multicolumn{3}{|c|}{$\begin{array}{c}\text { 1=Allotment System Used in } 4^{\text {th }} \text { Liberty } \\
\text { Loan }\end{array}$} \\
\hline & $(1)$ & $(2)$ & $(3)$ \\
\hline \multirow[t]{2}{*}{ Ln (Commercial Bank Assets) in State in 1914} & 0.068 & & 0.325 \\
\hline & $(0.050)$ & & $(0.205)$ \\
\hline \multirow[t]{2}{*}{ Fraction of State's Counties With an Investment Bank in 1914} & $-0.006^{* *}$ & & -0.001 \\
\hline & $(0.003)$ & & $(0.009)$ \\
\hline \multirow[t]{2}{*}{ Crop Price Index for State in 1914} & & 0.249 & 0.169 \\
\hline & & $(0.409)$ & $(0.429)$ \\
\hline \multirow[t]{2}{*}{ Ln(Population) of State in 1914} & & -0.182 & $-0.653 *$ \\
\hline & & $(0.186)$ & $(0.352)$ \\
\hline \multirow[t]{2}{*}{ Fraction of State's Population that was Non-White in 1914} & & -0.518 & -0.386 \\
\hline & & $(0.520)$ & $(0.518)$ \\
\hline \multirow[t]{2}{*}{ Fraction of State's Population that was Urban in 1914} & & -0.100 & -0.298 \\
\hline & & $(0.705)$ & $(0.687)$ \\
\hline \multirow[t]{2}{*}{ Fraction of State's Counties With City of More than 25,000 People } & & 0.179 & 0.682 \\
\hline & & $(0.550)$ & $(0.985)$ \\
\hline \multirow[t]{2}{*}{$\mathrm{Ln}$ (Number of Farms) in State in 1914} & & 0.229 & $0.364 *$ \\
\hline & & $(0.153)$ & $(0.187)$ \\
\hline \multirow[t]{2}{*}{ Fraction of State's Population that was Illiterate in 1914} & & -1.603 & -0.630 \\
\hline & & $(1.185)$ & $(1.221)$ \\
\hline F-statistic for joint significance & 2.30 & 2.23 & 2.00 \\
\hline$p$-value, F-statistic & 0.112 & 0.052 & 0.066 \\
\hline Observations & 48 & 48 & 48 \\
\hline
\end{tabular}


Table 3B:

\section{Relationship Between Allotment System and Earlier Changes}

This table presents OLS estimates of county-level regressions in which lagged versions of our main outcome variables are regressed on an indicator for the use of the allotment system for the fourth liberty loan ("Allotment system for $4^{\text {th }}$ Liberty Loan"), to check whether the counties of states that used the allotment system were evolving along different trends from those of other states. The outcome variables are the change in the log of total commercial bank assets, 1910-18; the change in the log of total commercial bank deposits, 1910-18; the change in the log of the total number of investment banks, 1914-18; and an indicator for gaining an investment bank during 1914-18. The dates over which the investment bank outcomes were calculated (1914-18) differ from those for the commercial bank outcomes because the investment bank data is not available prior to 1914. The sample spans the counties of all states that had both (i) data on state banks published from 1910 to 1929 and (ii) liberty bond subscription data for the fourth loan. "County-Level Controls" include 1910 values of the logarithm of population, the logarithm of the number of farms, the fraction of the population living in a location over 2,500 people, an indicator for whether the county contained a city of 25,000 people or more, the fraction of the population that was non-white, the fraction of the population that was born in Germany, the fraction of the population that was an immigrant from a country other than Germany, the fraction of the population that was illiterate, the crop price index, and an indicator for the presence of a Federal Reserve Bank or Branch interacted with the year-fixed effects. Robust standard errors clustered by state are presented in parentheses below the coefficients. $*$ denotes significance at $10 \% ; * *$ at $5 \%$ level and $* * *$ at $1 \%$ levels.

\begin{tabular}{|c|c|c|c|c|}
\hline & $\begin{array}{c}\Delta \operatorname{Ln} \text { (CB Assets), } \\
1910-18 \\
\end{array}$ & $\begin{array}{c}\Delta \operatorname{Ln}(\text { CB Deposits), } \\
1910-18 \\
\end{array}$ & $\begin{array}{c}\begin{array}{c}\Delta \operatorname{Ln}(\# \text { of IBs), } \\
1914-18\end{array} \\
\end{array}$ & $\begin{array}{c}\text { Gained an } \\
\text { IB, 1914-18 } \\
\end{array}$ \\
\hline & $(1)$ & $(2)$ & (3) & (4) \\
\hline \multirow[t]{2}{*}{ Allotment system for $4^{\text {th }}$ Liberty Loan } & 0.029 & 0.009 & $-0.042 *$ & -0.012 \\
\hline & $(0.023)$ & $(0.026)$ & $(0.021)$ & $(0.026)$ \\
\hline County-Level Controls & Yes & Yes & Yes & Yes \\
\hline Observations & 858 & 858 & 858 & 858 \\
\hline R-squared & 0.076 & 0.084 & 0.247 & 0.294 \\
\hline
\end{tabular}


Table 4:

Effects of Liberty Loan Subscriptions on Commercial and Investment Banks: IV Estimates

This table presents OLS and 2SLS estimates of Equation (4), in which we regress county financial outcomes on the county's subscription rate for the fourth liberty loan ("Liberty Bond 4th") interacted with an indicator for years after 1918 ("Post-1918”), in a panel with county and year fixed effects. In the IV specifications, we instrument for the fourth loan subscription rate interacted with post-1918 with an indicator for the use of the allotment system interacted ("Allotment System for 4th") with post-1918. The dependent variables are described in the column headings. The sample consists of the 858 counties in states that had both (i) data on state banks published from 1910 to 1929 and (ii) liberty bond subscription data for the fourth loan. For the commercial bank outcomes, the sample is a balanced panel from 1910 to 1929; for the investment bank outcomes, fewer years of data are available (see text). The weak instrument robust confidence sets are two-step identification-robust 95\% confidence sets proposed by Andrews (2018) based on linear combination tests, as implemented in the 'twostepweakiv' package in Stata using 1,000 grid points. The Effective F-statistics are those developed by Montiel Olea and Pfluger (2013). "County-Level Controls" include time-varying values of the logarithm of population, the logarithm of the number of farms, the fraction of the population living in a location over 2,500 people, an indicator for whether the county contained a city of 25,000 people or more, the fraction of the population that was non-white, the fraction of the population that was born in Germany, the fraction of the population that was an immigrant from a country other than Germany, the fraction of the population that was illiterate, the crop price index, as well as an indicator for the presence of a Federal Reserve Bank or Branch that is interacted with the year indicators. Robust standard errors clustered by state are presented in parentheses below the coefficients. * denotes significance at $10 \%$; * at $5 \%$ level and $* * *$ at $1 \%$ levels.

\begin{tabular}{|c|c|c|c|c|c|c|c|c|}
\hline & \multicolumn{2}{|c|}{$\begin{array}{c}\text { Ln(Commercial Bank } \\
\text { Assets) }\end{array}$} & \multicolumn{2}{|c|}{$\begin{array}{c}\text { Ln(Commercial Bank } \\
\text { Deposits) }\end{array}$} & \multicolumn{2}{|c|}{$\begin{array}{c}\text { Ln(Number of } \\
\text { Investment Banks) }\end{array}$} & \multicolumn{2}{|c|}{ 1=Investment Bank Present } \\
\hline & $\begin{array}{c}\text { OLS } \\
(1)\end{array}$ & $\begin{array}{l}\text { IV } \\
\text { (2) }\end{array}$ & $\begin{array}{l}\text { OLS } \\
\text { (3) }\end{array}$ & $\begin{array}{l}\text { IV } \\
\text { (4) }\end{array}$ & $\begin{array}{c}\text { OLS } \\
(5)\end{array}$ & $\begin{array}{l}\text { IV } \\
(6) \\
\end{array}$ & $\begin{array}{c}\text { OLS } \\
(7)\end{array}$ & $\begin{array}{l}\mathbf{I V} \\
(8) \\
\end{array}$ \\
\hline Liberty Bond 4th $\times$ Post-1918 & $\begin{array}{c}-0.013^{* * *} * \\
(0.002)\end{array}$ & $\begin{array}{c}-0.021^{* * *} \\
(0.005)\end{array}$ & $\begin{array}{c}-0.014^{* * *} * \\
(0.002)\end{array}$ & $\begin{array}{c}-0.025^{* * *} * \\
(0.005)\end{array}$ & $\begin{array}{c}0.005^{* * *} * \\
(0.001)\end{array}$ & $\begin{array}{c}0.005 \\
(0.003)\end{array}$ & $\begin{array}{c}0.003 * * * \\
(0.001)\end{array}$ & $\begin{array}{l}0.003 * \\
(0.002)\end{array}$ \\
\hline Weak-IV Robust Confidence Set & - & {$[-.033,-.010]$} & - & {$[-.039,-.015]$} & - & {$[-.003, .012]$} & - & {$[-.001, .008]$} \\
\hline County-Level Controls & Yes & Yes & Yes & Yes & Yes & Yes & Yes & Yes \\
\hline Year Effects, County Effects & Yes & Yes & Yes & Yes & Yes & Yes & Yes & Yes \\
\hline Observations & 17287 & 17287 & 17287 & 17287 & 7784 & 7784 & 7784 & 7784 \\
\hline Kleibergen-Paap F-statistic & - & 13.66 & - & 13.66 & - & 16.63 & - & 16.63 \\
\hline \multirow[t]{2}{*}{ Effective F-statistic } & - & 12.97 & - & 12.97 & - & 14.77 & - & 14.77 \\
\hline & \multicolumn{8}{|c|}{ First-Stage Regression: Liberty Bond 4th $\times$ Post-1918 } \\
\hline Allotment System for 4 th $\times$ Post- 1918 & & $\begin{array}{c}8.143 * * * \\
(2.203)\end{array}$ & & $\begin{array}{l}8.143 * * * \\
(2.203)\end{array}$ & & $\begin{array}{c}8.983 * * * \\
(2.203)\end{array}$ & & $\begin{array}{c}8.983 * * * \\
(2.203) \\
\end{array}$ \\
\hline County-Level Controls & & Yes & & Yes & & Yes & & Yes \\
\hline Year Effects, County Effects & & Yes & & Yes & & Yes & & Yes \\
\hline
\end{tabular}




\title{
Effects of Liberty Loan Subscriptions on Commercial and Investment Banks: IV Estimates, Alternative Specification
}

\begin{abstract}
This table presents OLS and 2SLS estimates of Equation (5), in which we regress county financial outcomes on the county subscription rate for the third liberty loan ("Liberty Bond 3rd") interacted with an indicator for years after 1918 ("Post-1918"), and the change in the county's subscription rate from the third to the fourth loan ("Liberty Bond Diff"), also interacted with post-1918, in a panel with county and year fixed effects. In the IV specifications we instrument for the change in the county's subscription rate from the third to the fourth loan interacted with post-1918 with an indicator for a change to the allotment system with the fourth loan ("Switch to Allotment System") interacted with post-1918. The first stage regressions in the IV specifications also include the subscription rate for the 3rd loan. The dependent variables are described in the column headings. The sample consists of the 858 counties in states that had both (i) data on state banks published from 1910 to 1929 and (ii) liberty bond subscription data for the fourth loan. For the commercial bank outcomes, the sample is a balanced panel from 1910 to 1929; for the investment bank outcomes, fewer years of data are available (see text). The weak instrument robust confidence sets are two-step identification-robust $95 \%$ confidence sets proposed by Andrews (2018) based on linear combination tests, as implemented in the 'twostepweakiv' package in Stata using 1,000 grid points. The Effective F-statistics are those developed by Montiel Olea and Pfluger (2013). "County-Level Controls" include time-varying values of the logarithm of population, the logarithm of the number of farms, the fraction of the population living in a location over 2,500 people, an indicator for whether the county contained a city of 25,000 people or more, the fraction of the population that was non-white, the fraction of the population that was born in Germany, the fraction of the population that was an immigrant from a country other than Germany, the fraction of the population that was illiterate, the crop price index, as well as an indicator for the presence of a Federal Reserve Bank or Branch that is interacted with the year indicators. Robust standard errors clustered by state are presented in parentheses below the coefficients. * denotes significance at $10 \%$; ** at $5 \%$ level and $* * *$ at $1 \%$ levels.
\end{abstract}

\begin{tabular}{|c|c|c|c|c|c|c|c|c|}
\hline & \multicolumn{2}{|c|}{$\begin{array}{c}\text { Ln(Commercial Bank } \\
\text { Assets) }\end{array}$} & \multicolumn{2}{|c|}{$\begin{array}{c}\text { Ln(Commercial Bank } \\
\text { Deposits) }\end{array}$} & \multicolumn{2}{|c|}{$\begin{array}{c}\text { Ln(Number of } \\
\text { Investment Banks) }\end{array}$} & \multicolumn{2}{|c|}{$\begin{array}{c}\text { 1=Investment Bank } \\
\text { Present }\end{array}$} \\
\hline & $\begin{array}{c}\text { OLS } \\
(1) \\
\end{array}$ & $\begin{array}{l}\text { IV } \\
(2) \\
\end{array}$ & $\begin{array}{c}\text { OLS } \\
(3) \\
\end{array}$ & $\begin{array}{l}\text { IV } \\
(4) \\
\end{array}$ & $\begin{array}{c}\text { OLS } \\
(5) \\
\end{array}$ & $\begin{array}{l}\mathbf{I V} \\
(6) \\
\end{array}$ & $\begin{array}{c}\text { OLS } \\
(7) \\
\end{array}$ & $\begin{array}{l}\text { IV } \\
(8) \\
\end{array}$ \\
\hline Liberty Bond 3rd $\times$ Post- 1918 & $\begin{array}{c}-0.014^{* * *} \\
(0.002)\end{array}$ & $\begin{array}{c}-0.025 * * * \\
(0.004)\end{array}$ & $\begin{array}{c}-0.015^{* * *} * \\
(0.002)\end{array}$ & $\begin{array}{c}-0.027^{* * *} \\
(0.004)\end{array}$ & $\begin{array}{c}0.005 * * * \\
(0.001)\end{array}$ & $\begin{array}{c}0.007 * * * \\
(0.001)\end{array}$ & $\begin{array}{c}0.004 * * * \\
(0.001)\end{array}$ & $\begin{array}{c}0.005 * * * \\
(0.001)\end{array}$ \\
\hline Liberty Bond Diff $\times$ Post- 1918 & $\begin{array}{c}-0.010^{* * *} \\
(0.002)\end{array}$ & $\begin{array}{c}-0.049 * * * \\
(0.004)\end{array}$ & $\begin{array}{c}-0.011^{* * *} \\
(0.003)\end{array}$ & $\begin{array}{c}-0.050^{* * *} * \\
(0.009)\end{array}$ & $\begin{array}{c}0.004 \\
(0.003)\end{array}$ & $\begin{array}{c}0.010^{* *} \\
(0.005)\end{array}$ & $\begin{array}{c}0.001 \\
(0.002)\end{array}$ & $\begin{array}{l}0.006 * \\
(0.003)\end{array}$ \\
\hline Weak-IV Robust Confidence Set & - & {$[-.071,-.034]$} & - & {$[-.072,-.035]$} & - & {$[.002, .021]$} & - & {$[.001, .014]$} \\
\hline County-Level Controls & Yes & Yes & Yes & Yes & Yes & Yes & Yes & Yes \\
\hline Year Effects, County Effects & Yes & Yes & Yes & Yes & Yes & Yes & Yes & Yes \\
\hline Observations & 13668 & 13668 & 13668 & 13668 & 6154 & 6154 & 6154 & 6154 \\
\hline Kleibergen-Paap F-statistic & - & 43.93 & - & 43.93 & - & 42.65 & - & 42.65 \\
\hline Effective F-statistic & - & 41.71 & - & 41.71 & - & 37.87 & - & 37.87 \\
\hline & \multicolumn{8}{|c|}{ First-Stage Regression: Liberty Bond 4th $\times$ Post-1918 } \\
\hline Switch to Allotment System $\times$ Post- 1918 & & $\begin{array}{l}5.353 * * * \\
(0.808)\end{array}$ & & $\begin{array}{c}5.353^{* * * *} \\
(0.808)\end{array}$ & & $\begin{array}{c}5.540^{* * * *} \\
(0.848)\end{array}$ & & $\begin{array}{c}5.540 * * * \\
(0.848)\end{array}$ \\
\hline County-Level Controls & & Yes & & Yes & & Yes & & Yes \\
\hline Year Effects, County Effects & & Yes & & Yes & & Yes & & Yes \\
\hline
\end{tabular}




\section{Table 6:}

\section{Effects of Liberty Loan Subscriptions on Financial Asset Ownership, 1930s}

This table presents estimates of cross-sectional linear probability models of the determinants of individual-level ownership of stocks and bonds as reported in five Gallup polls from 1935-38 (see equations (6A) and (6B)). The dependent variable is an indicator for whether or not a respondent reported owning stocks or bonds, which is regressed on state-level liberty bond subscription rates, either for the fourth loan ("State Liberty Bond Subscription Rate, $4^{\text {th }}$ Loan ") in columns (1) and (2), or for the third loan ("State Liberty Bond Subscription Rate, $3^{\text {rd }}$ Loan") and the change from the third to the fourth ("State Liberty Bond Subscription Rate Diff, $3^{\text {rd }}$ to $4^{\text {th }}$ Loan ") in columns (3) and (4). Each regression includes indicator variables for the specific poll, and is weighted (see text). In the IV specification of column (2), we instrument for the state's fourth loan subscription rate with an indicator for use of the allotment system, and in column (4), we instrument for the change in the state subscription rate from the $3^{\text {rd }}$ to the $4^{\text {th }}$ loan using an indicator for a switch to the allotment system in the $4^{\text {th }}$ loan. The first stage regression in column (4) also includes the state subscription rate for the $3^{\text {rd }}$ loan. Demographic controls include the respondent's age, age squared, and indicator variables for gender and race. Occupation controls include indicators for white collar workers, laborers, the unemployed, and other occupations, with professionals excluded. Location controls include an indicator for whether a respondent lived on a farm or in a small town. The Effective F-statistics are those developed by Montiel Olea and Pfluger (2013). The weak instrument robust confidence sets are two-step identificationrobust 95\% confidence sets proposed by Andrews (2018) based on linear combination tests, as implemented in the 'twostepweakiv' package in Stata using 1,000 grid points. Standard errors clustered by state presented in parentheses. * denotes significance at $10 \% ; * *$ at $5 \%$ level and $* * *$ at $1 \%$.

\begin{tabular}{|c|c|c|c|c|}
\hline & $\begin{array}{c}\text { OLS } \\
(1)\end{array}$ & $\begin{array}{l}\text { IV } \\
(2)\end{array}$ & $\begin{array}{c}\text { OLS } \\
(3)\end{array}$ & $\begin{array}{l}\text { IV } \\
(4)\end{array}$ \\
\hline State Liberty Bond Subscription Rate, $4^{\text {th }}$ Loan & $\begin{array}{c}0.004 * * * \\
(0.001)\end{array}$ & $\begin{array}{c}0.004 * * * \\
(0.001)\end{array}$ & & \\
\hline State Liberty Bond Subscription Rate, $3^{\text {rd }}$ Loan & & & $\begin{array}{c}0.004 * * * \\
(0.001)\end{array}$ & $\begin{array}{c}0.004 * * * \\
(0.001)\end{array}$ \\
\hline State Liberty Bond Subscription Rate Diff, $3^{\text {rd }}$ to $4^{\text {th }}$ Loan & & & $\begin{array}{c}0.004 * * * \\
(0.001)\end{array}$ & $\begin{array}{l}0.003 * \\
(0.002)\end{array}$ \\
\hline Weak-Instrument Robust Confidence Set & - & {$[.002, .007]$} & - & {$[-.003, .009]$} \\
\hline Demographic Controls & Yes & Yes & Yes & Yes \\
\hline Occupation Controls & Yes & Yes & Yes & Yes \\
\hline Location Controls & Yes & Yes & Yes & Yes \\
\hline Observations & 13,393 & 13,393 & 13,393 & 13,393 \\
\hline Kleibergen-Paap F-statistic & - & 5.97 & - & 7.03 \\
\hline Effective F-statistic & - & 5.96 & - & 7.02 \\
\hline & & $\begin{array}{c}\text { First Stage: } \\
\text { State } \\
\text { Subscription } \\
\text { Rate, 4th }\end{array}$ & & $\begin{array}{c}\text { First Stage: } \\
\text { Subscription } \\
\text { Rate Diff, } \\
3^{\text {rd }} \text { to } 4^{\text {th }}\end{array}$ \\
\hline Allotment System for $4^{\text {th }}$ Loan & & $\begin{array}{c}5.879 * * \\
(2.406)\end{array}$ & & \\
\hline Switch to Allotment System for $4^{\text {th }}$ & & & & $\begin{array}{c}2.810 * * * \\
(1.060)\end{array}$ \\
\hline Demographic Controls & Yes & Yes & Yes & Yes \\
\hline Occupation Controls & Yes & Yes & Yes & Yes \\
\hline Location Controls & Yes & Yes & Yes & Yes \\
\hline
\end{tabular}



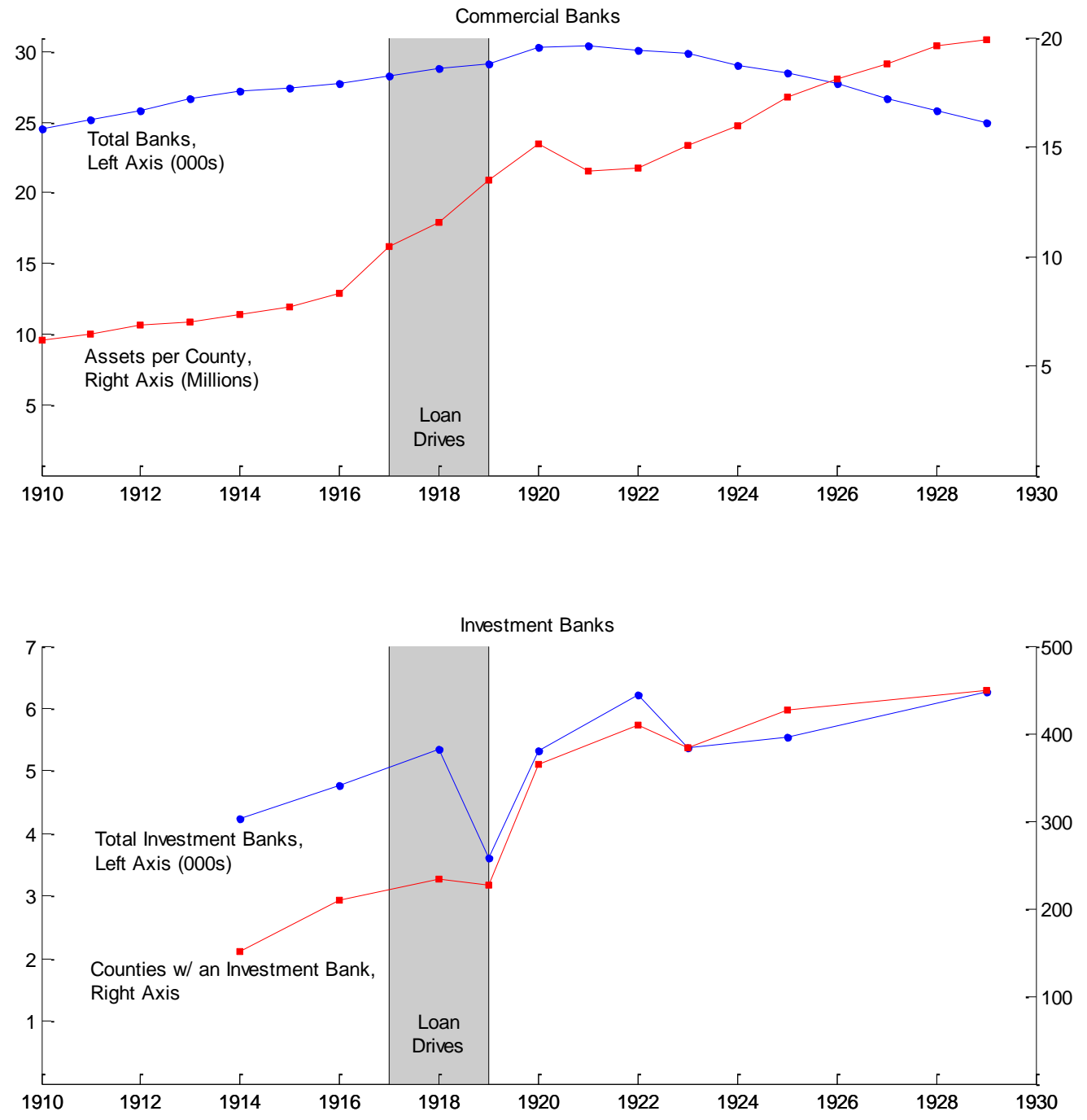

Figure 1:

Changes in Commercial Banks (Top) and Investment Banks (Bottom), 1910-29

The top panel of this figure shows the total number of commercial banks in the United States, in blue, and the value of commercial bank assets per county, in red. The shaded grey area represents the period of the liberty loan drives. The bottom panel shows the total number of investment banks, in blue, and the number of counties with an investment bank, in red. 


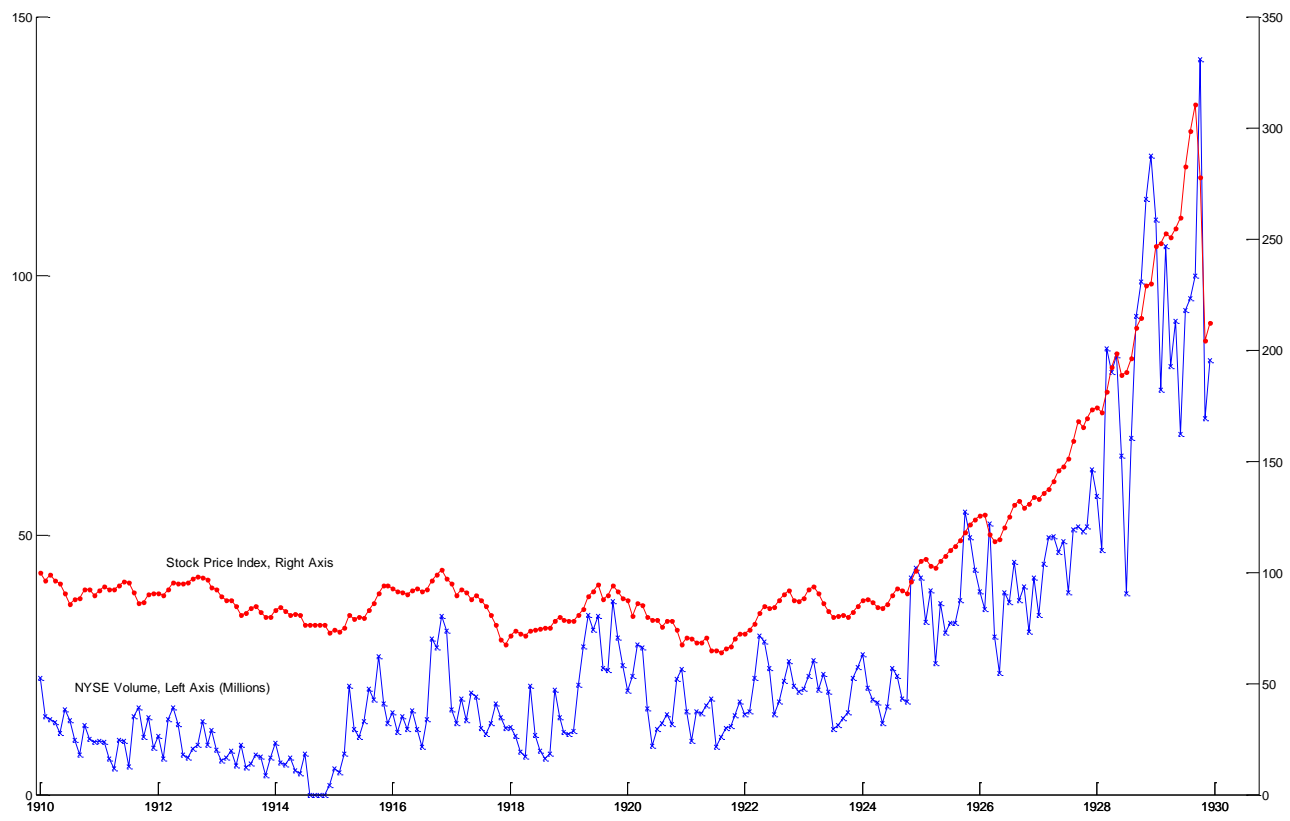

Figure 2:

Stock Prices and NYSE Trading Volumes, 1910-29

This figure presents monthly data on the volume of shares traded on the NYSE, in blue, and scaled by the left axis, and Robert Shiller's (2000) share price index, in red and normalized to January $1910=$ 100 , scaled by the right axis. 


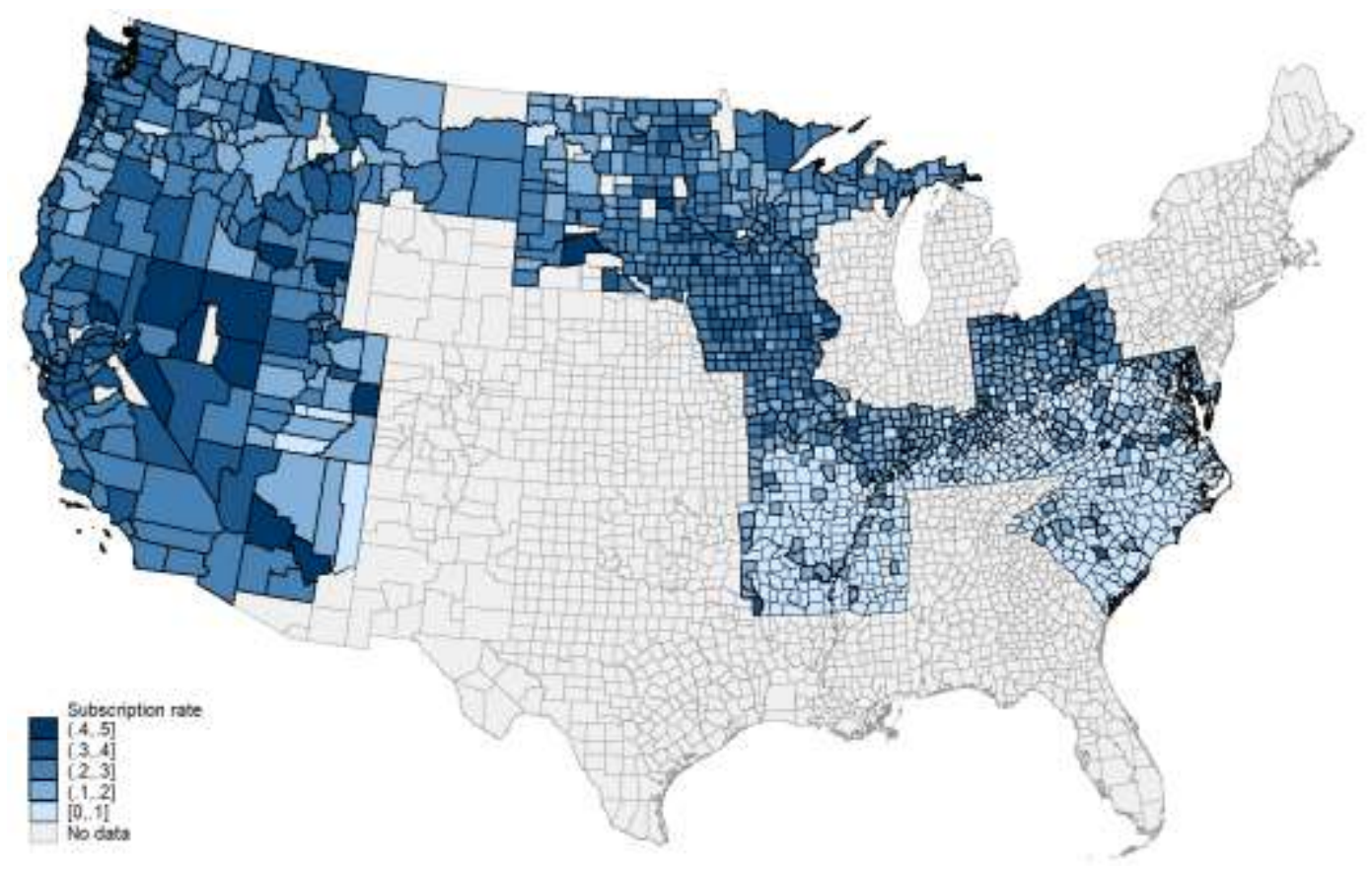

Figure 3:

Subscription Rates, 4th Liberty Loan

This figure shows the available data for the county subscription rates for the 4th liberty loan. The county boundaries in the figure are those of 1910 . 

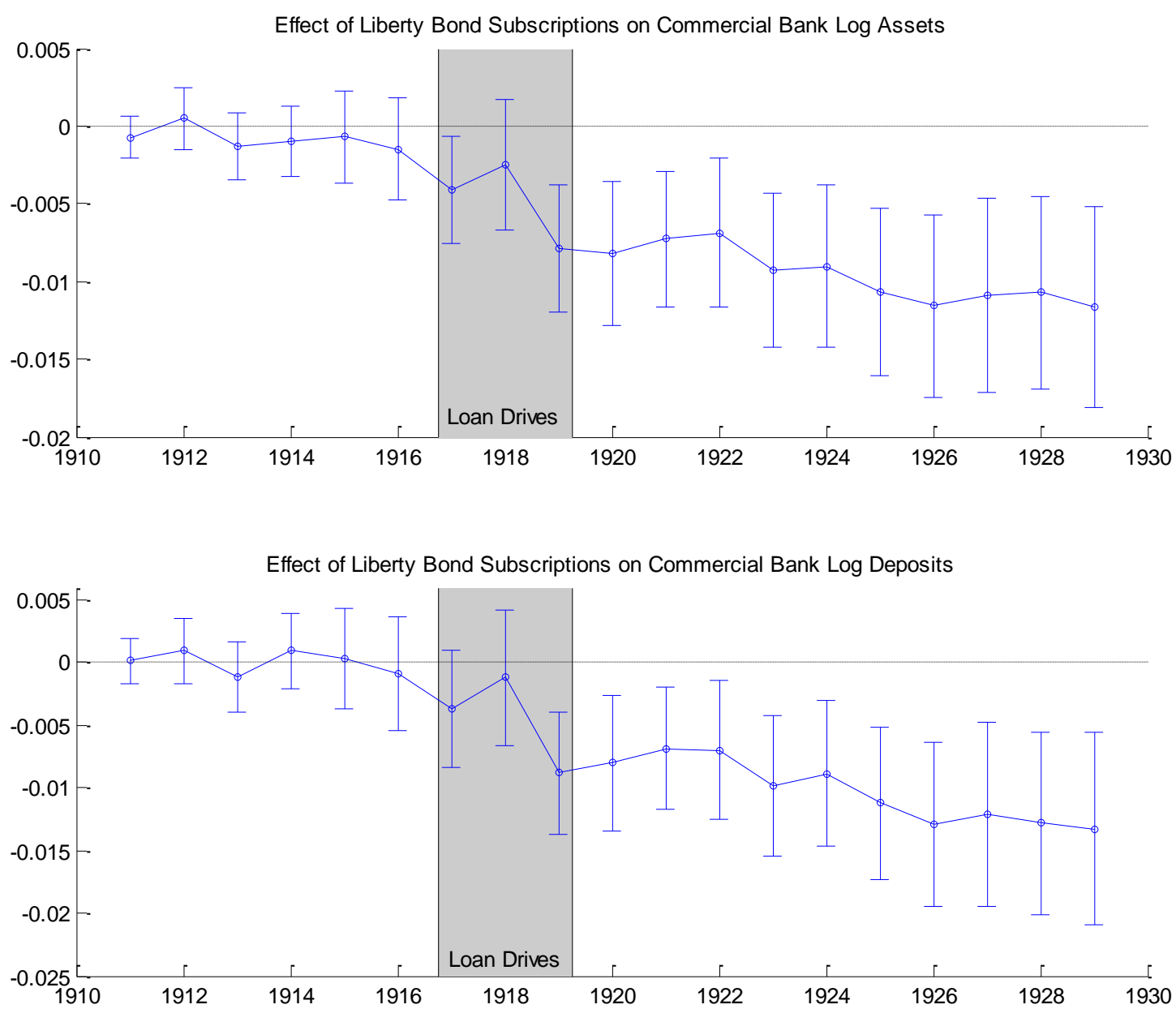

Figure 4:

Effect of Liberty Bonds on Commercial Banks, 1910-29

The panels of this figure shows the annual effect, relative to 1910, of liberty bond subscription rates on the logarithm of commercial bank assets (top) and on the logarithm of commercial bank deposits (bottom), as estimated from equation (1). The shaded grey area represents the period of the liberty loan drives. 

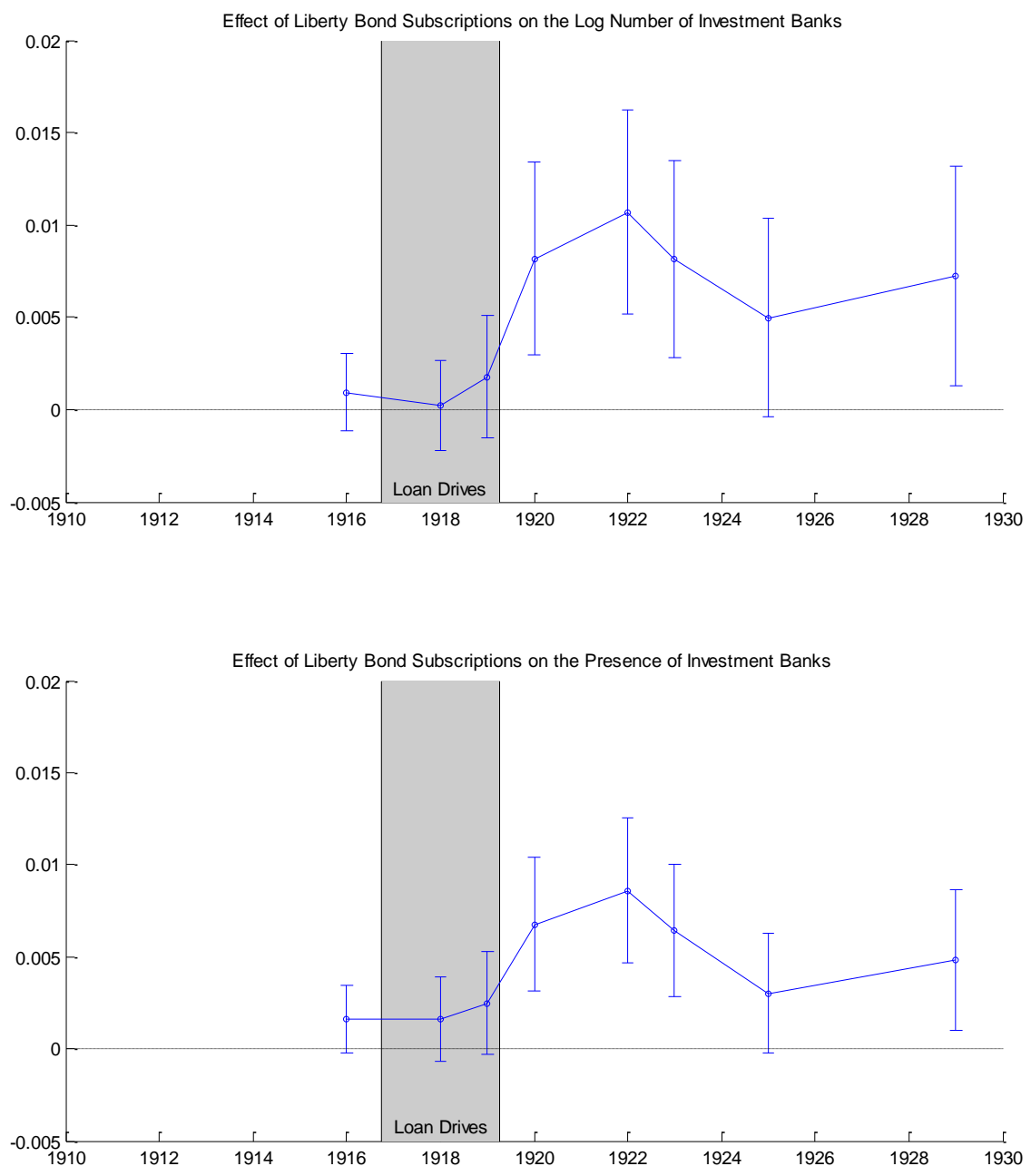

Figure 5:

Effect of Liberty Bonds on Investment Banks, 1914-29

This figure shows the annual effect, relative to 1914, of liberty bond subscription rates on the logarithm number of investment banks in a county (top), and on an indicator for the presence of at least one investment bank (bottom), as estimated from equation (1). The shaded grey area represents the period of the liberty loan drives. The odd pattern of dates reflects the available years of data. 

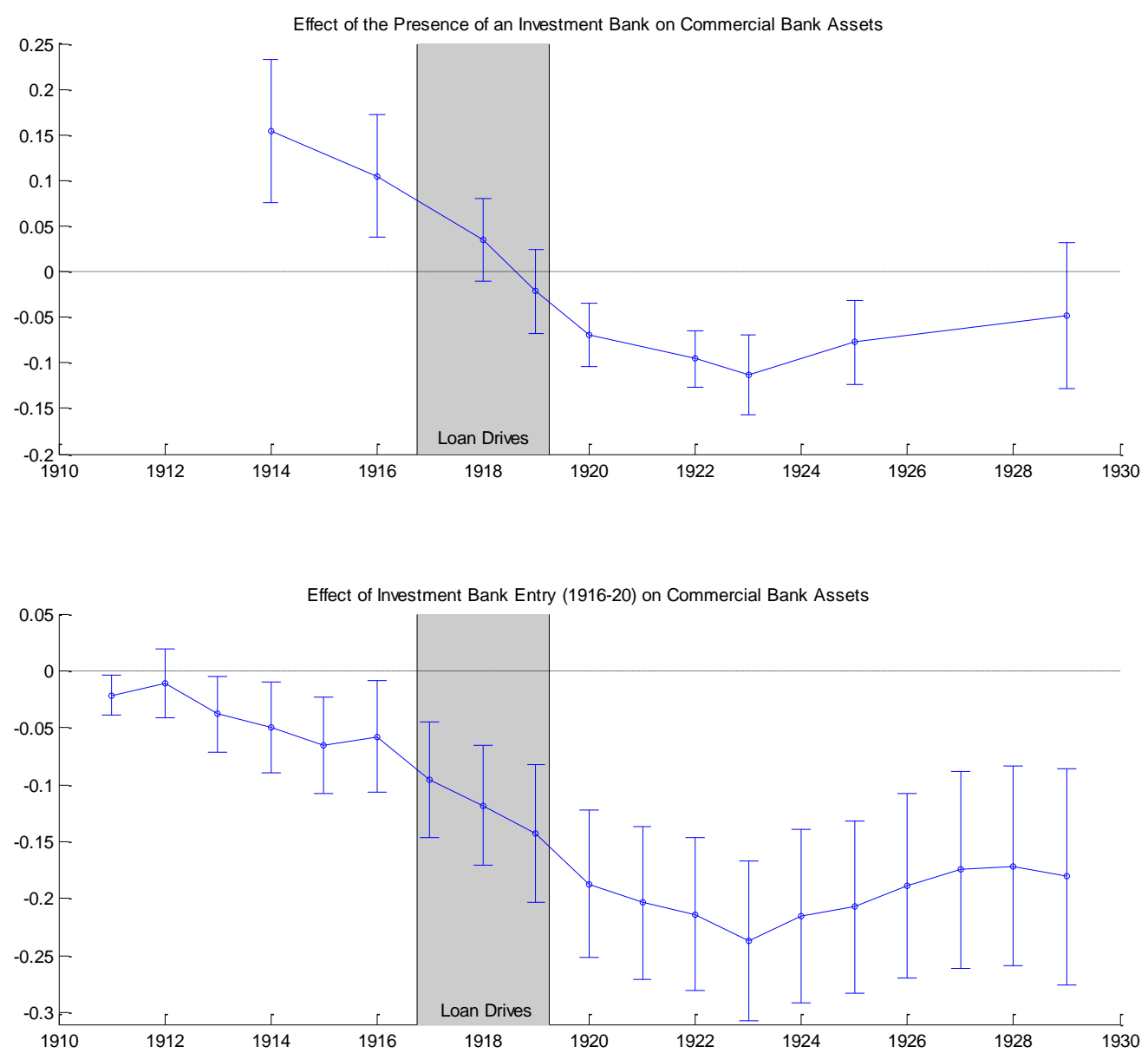

Figure 6:

Effects of Investment Banks on Commercial Bank Assets, 1914-29

The top panel of this figure presents annual estimates of the relationship between the presence of an investment bank and the logarithm of commercial bank assets, as estimated from equation (2). The odd pattern of dates in the top panel reflects the available years of data. The lower panel shows the annual effect, relative to 1910, of having gained at least one investment bank during 1916-1920 on the logarithm of commercial bank assets, as estimated from equation (3). The shaded grey area represents the period of the liberty loan drives. 


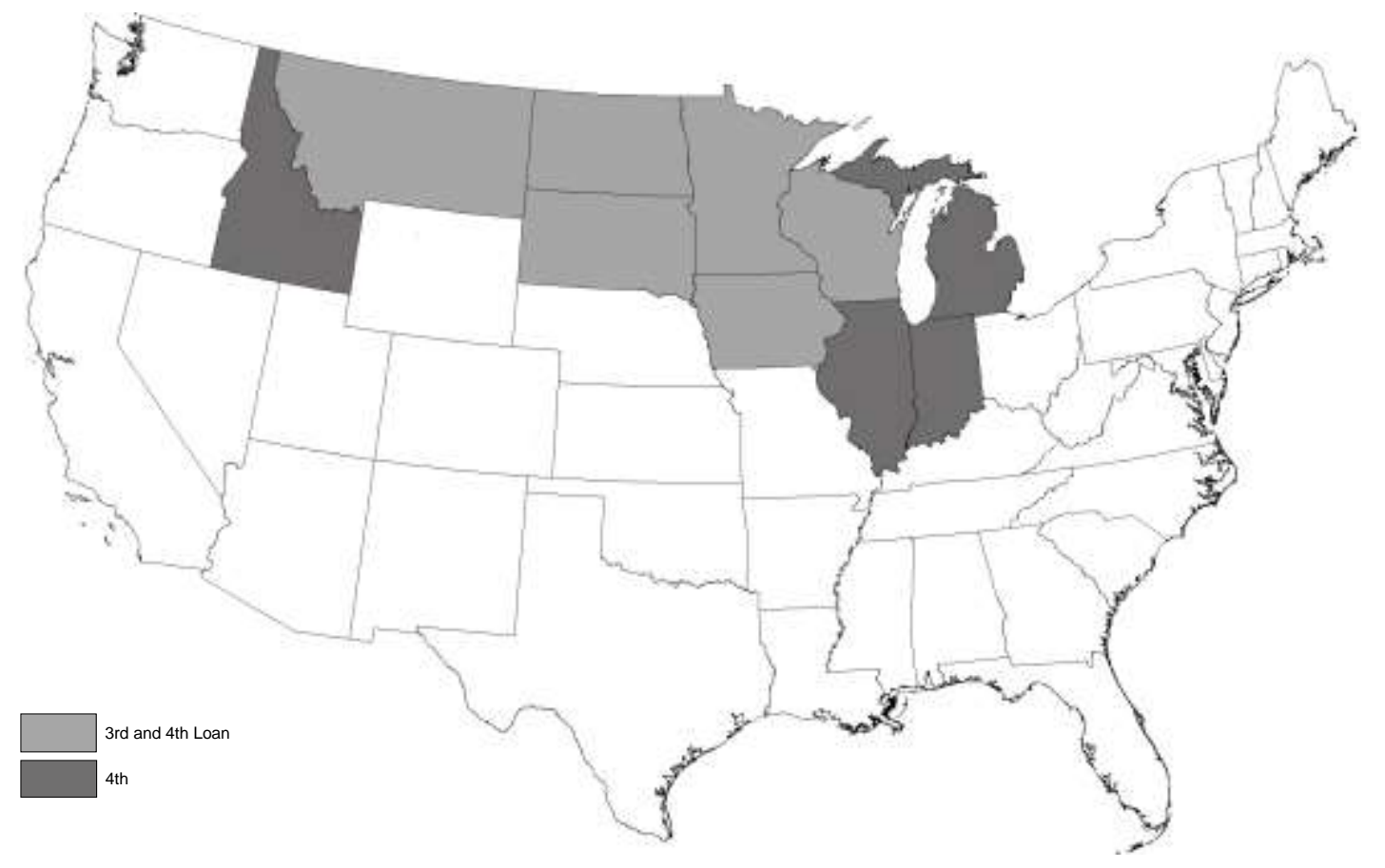

Figure 7:

States Employing the Allotment System in the $4^{\text {th }}$ Liberty Loan

The shaded states in the map utilized the allotment system in the drive for the $4^{\text {th }}$ liberty loan. The states shaded in the lighter color had already used the allotment system in the drive for the $3^{\text {rd }}$ loan; the states shaded in the darker color used it for the first time in the drive for the $4^{\text {th }}$ loan. Sources: National Woman's Liberty Loan Committee (1918), Seventh Federal Reserve District Liberty Loan Committee (1918), Ninth Federal Reserve District Liberty Loan Committee (1918), Federal Reserve Board (1918). 

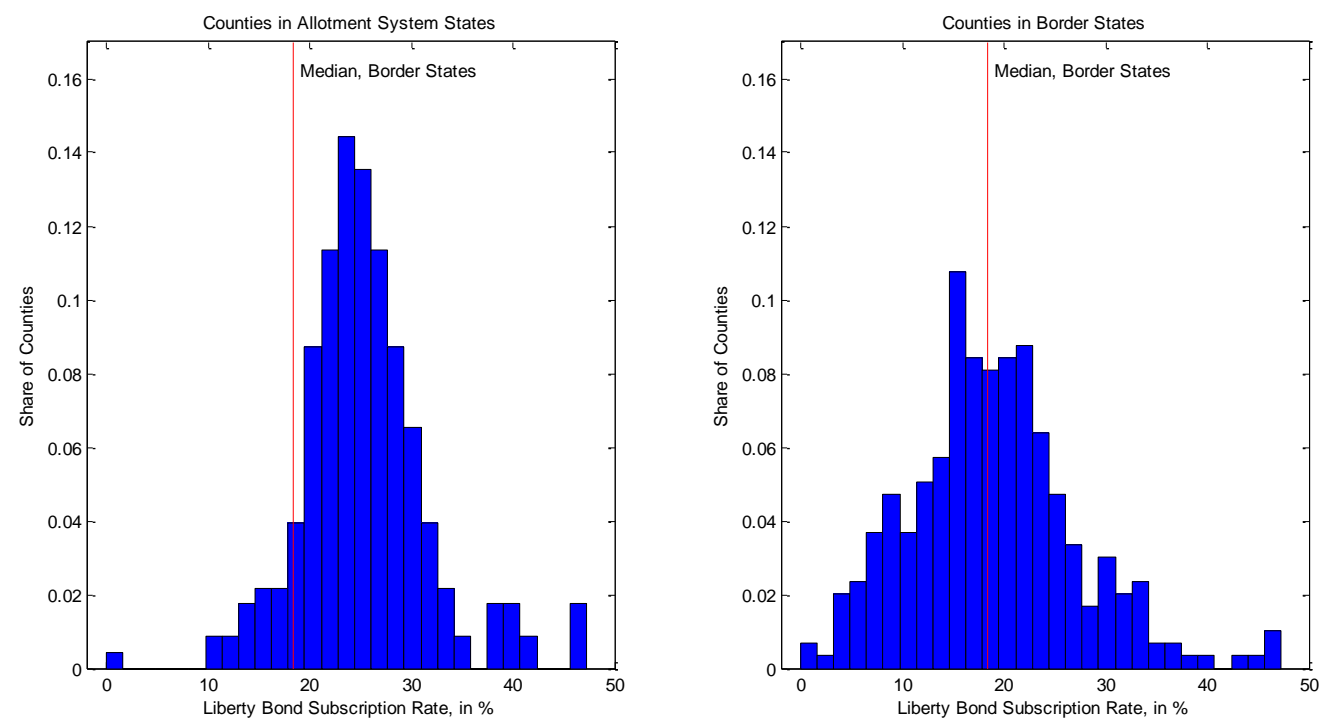

Figure 8:

Distribution of Subscription Rates, $4^{\text {th }}$ Liberty Loan:

Allotment System vs. Neighboring Counties

This figure presents the distribution of county subscription rates for the fourth liberty loan for counties that used the allotment system vs. counties in bordering states that did not ("Border States"). The left panel plots the distribution for 220 sample counties in Wisconsin, South Dakota, Montana, Michigan, Idaho and Iowa. The 297 sample counties in the bordering states on the right are those of Washington, Oregon, Ohio and Missouri as well as those located in the Kansas City Fed District of Illinois. The vertical line denotes the median subscription rate in border state counties, which was 18.37 percent. 


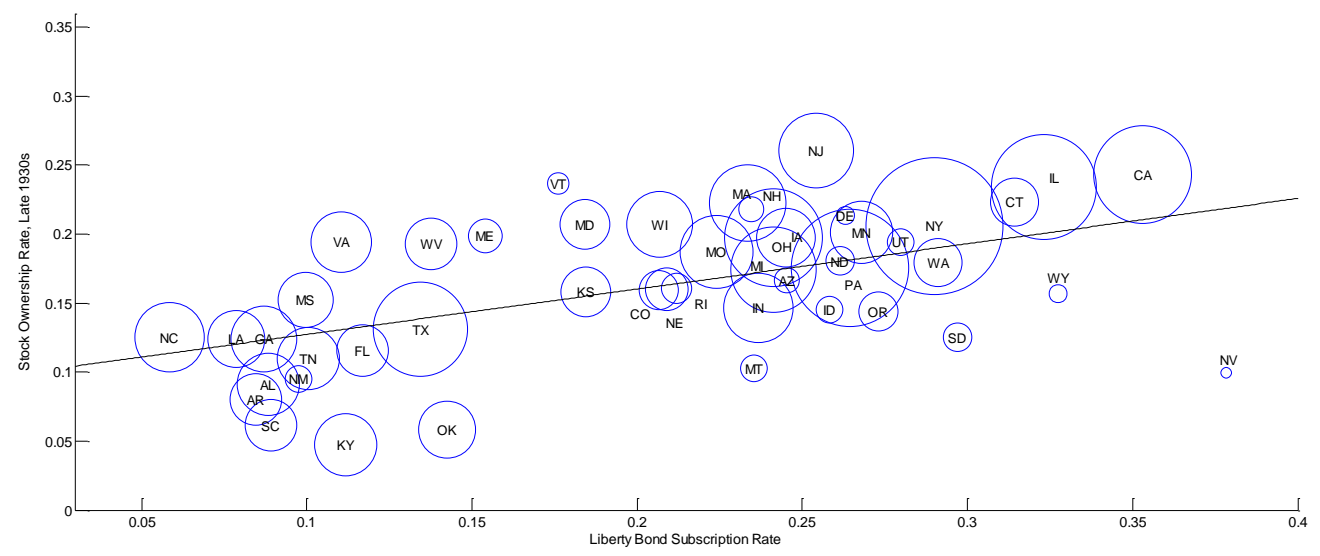

Figure 9:

State-Level Relationship Between Stock and Bond Ownership in the Late 1930s and Liberty Bond Subscription Rates

This figure shows the average stock and bond ownership rate by state, as calculated from Gallup poll data from the late 1930s, plotted against the state-level $4^{\text {th }}$ liberty bond subscription rate, as reported by the U.S. Treasury (1920). The state-level stock ownership rates are calculated as probability-weighted averages of survey respondent rates; see text. The area of each state's marker is proportional to its 1930 population. 


\section{APPENDIX}

For Online Publication Only 

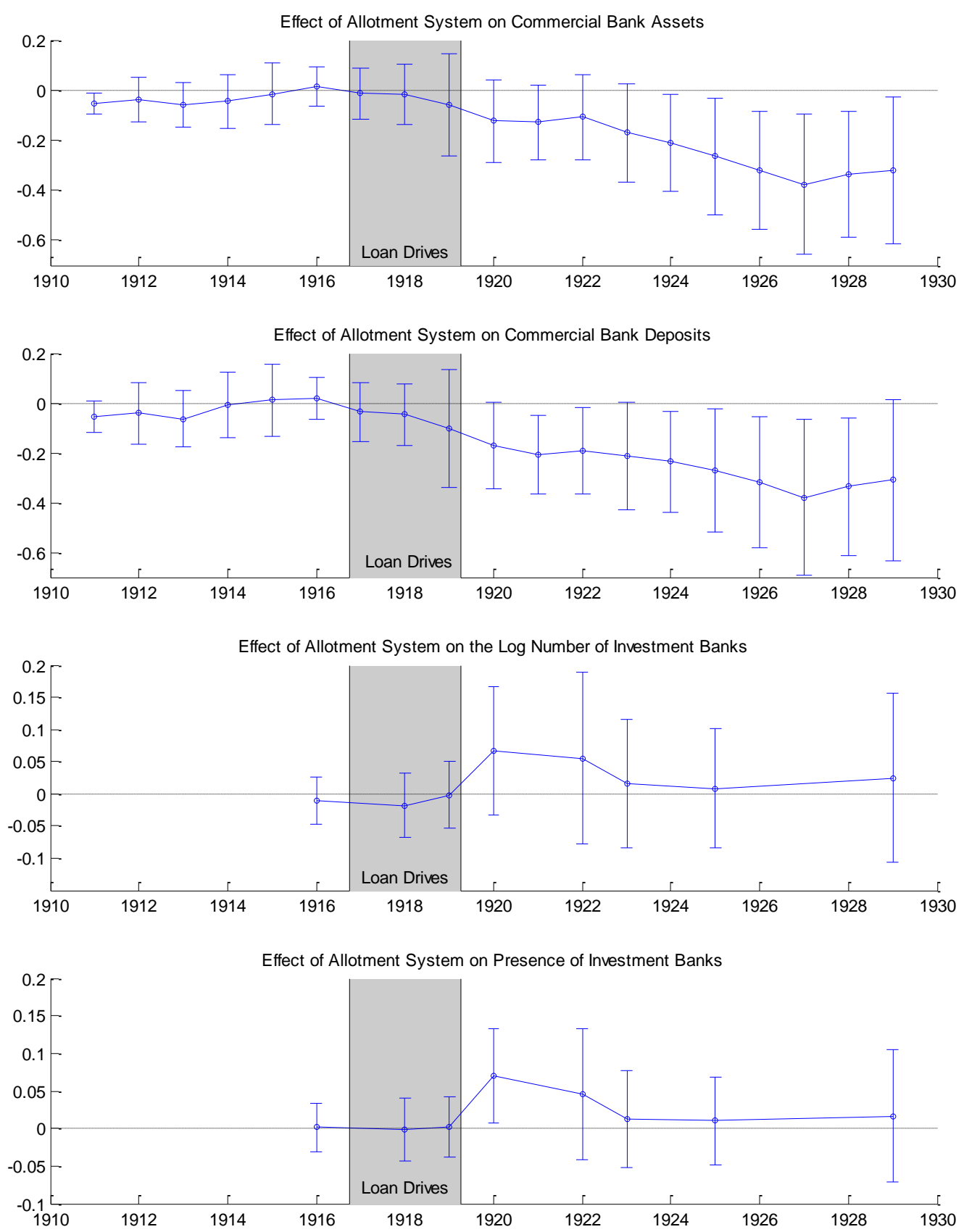

Figure A1:

Effect of Allotment System on Financial Outcomes, 1910-29

Notes: The figure shows estimates obtained from regressions of log commercial bank assets and deposits (top two figures) as well as of the log number of investment banks and an indicator for the presence of an investment bank (bottom two figures), in models that control for county characteristics and county fixed effects and standard errors clustered by state. The shaded grey area represents the period of the liberty loan drives. This is effectively an event-study version of the reduced form of Equation (4). 
Table A1:

\section{Effects of Liberty Loan Subscriptions on Commercial and Investment Banks, Dropping Purely Rural Counties}

\begin{tabular}{|c|c|c|c|c|c|c|c|c|}
\hline & \multicolumn{2}{|c|}{$\begin{array}{c}\text { Ln(Commercial Bank } \\
\text { Assets) }\end{array}$} & \multicolumn{2}{|c|}{$\begin{array}{c}\text { Ln(Commercial Bank } \\
\text { Deposits) }\end{array}$} & \multicolumn{2}{|c|}{$\begin{array}{c}\text { Ln(Number of } \\
\text { Investment Banks) }\end{array}$} & \multicolumn{2}{|c|}{ 1=Investment Bank Present } \\
\hline & & IV-Drop & & IV-Drop & & IV-Drop & & IV-Drop \\
\hline & $\begin{array}{l}\text { IV } \\
(1) \\
\end{array}$ & $\begin{array}{c}\text { Urban } \\
(2)\end{array}$ & $\begin{array}{l}\text { IV } \\
(3) \\
\end{array}$ & $\begin{array}{c}\text { Urban } \\
(4)\end{array}$ & $\begin{array}{l}\text { IV } \\
(5) \\
\end{array}$ & $\begin{array}{c}\text { Urban } \\
(6)\end{array}$ & $\begin{array}{l}\text { IV } \\
(7)\end{array}$ & $\begin{array}{c}\text { Urban } \\
(8) \\
\end{array}$ \\
\hline Liberty Bond 4th $\times$ Post- 1918 & $\begin{array}{l}-0.021 * * * \\
(0.005)\end{array}$ & $\begin{array}{c}-0.025 * * * \\
(0.008)\end{array}$ & $\begin{array}{l}-0.025 * * * \\
(0.005)\end{array}$ & $\begin{array}{c}-0.030^{* * * *} \\
(0.008)\end{array}$ & $\begin{array}{c}0.005 \\
(0.003)\end{array}$ & $\begin{array}{l}0.014^{* *} \\
(0.005)\end{array}$ & $\begin{array}{l}0.003^{*} \\
(0.002)\end{array}$ & $\begin{array}{c}0.010^{* *} \\
(0.004)\end{array}$ \\
\hline Weak-IV Robust Confidence Set & {$[-.033,-.010]$} & {$[-.055,-.012]$} & {$[-.039,-.015]$} & {$[-.065,-.017]$} & {$[-.003, .012]$} & {$[.006, .033]$} & {$[-.001, .008]$} & {$[.004, .023]$} \\
\hline County-Level Controls & Yes & Yes & Yes & Yes & Yes & Yes & Yes & Yes \\
\hline Year Effects, County Effects & Yes & Yes & Yes & Yes & Yes & Yes & Yes & Yes \\
\hline Observations & 17287 & 10297 & 17287 & 10297 & 7784 & 7127 & 7784 & 7127 \\
\hline Kleibergen-Paap F-statistic & 13.66 & 8.79 & 13.66 & 8.79 & 16.63 & 10.88 & 16.63 & 10.88 \\
\hline Effective F-statistic & 12.97 & 8.35 & 12.97 & 8.35 & 14.77 & 9.66 & 14.77 & 9.66 \\
\hline
\end{tabular}

Notes: This table presents 2SLS estimates of Equation (4). Columns (1), (3), (5) and (7) include the full sample, and are the same as reported in Table 4. In columns (2), (4), (6) and (8) we drop counties that did not contain an urban center with at least 2,500 people. In the first stage, we instrument for the subscription rate for the $4^{\text {th }}$ liberty loan interacted with a post-1918 indicator ("Liberty Bond 4th $\times$ Post-1918") using an indicator for the use of the allotment system interacted with post-1918. The dependent variables are described in the column headings. The weak instrument robust confidence sets are two-step identification-robust confidence sets proposed by Andrews (2018) based on linear combination tests, as implemented in the 'twostepweakiv' package in Stata using 1,000 grid points. "County-Level Controls" include time-varying values of the logarithm of population, the logarithm of the number of farms, the fraction of the population living in a location over 2,500 people, an indicator for whether the county contained a city of 25,000 people or more, the fraction of the population that was non-white, the fraction of the population that was born in Germany, the fraction of the population that was an immigrant from a country other than Germany, the fraction of the population that was illiterate, and the crop price index, as well as an indicator for the presence of a Federal Reserve Bank or Branch interacted with the year indicators. Robust standard errors clustered by state are presented in parentheses below the coefficients. $*$ denotes significance at $10 \% ; * *$ at $5 \%$ level and $* * *$ at $1 \%$ levels. 
Table A2:

Liberty Loan Subscription Rates, In Percentage Points

\begin{tabular}{lcccccc}
\hline & $\boldsymbol{N}$ & Mean & SD & P25 & P75 & $\left.\boldsymbol{\rho ~ ( 4 ~}^{\text {th }}\right)$ \\
& $(1)$ & $(2)$ & $(3)$ & $(4)$ & $(5)$ & $(6)$ \\
\hline Fourth Liberty Loan & 858 & 16.534 & 10.228 & 7.316 & 24.024 & - \\
Third Liberty Loan & 678 & 13.795 & 10.694 & 4.198 & 21.700 & 0.812 \\
Change From 3 $^{\text {rd }}$ to $4^{\text {th }}$ & 678 & 3.300 & 6.538 & 0.141 & 6.199 & 0.297 \\
\hline
\end{tabular}

Notes: This table presents summary statistics for county subscription rates to the fourth liberty loan, the third liberty loan, and the change from the $3^{\text {rd }}$ to the $4^{\text {th }}$. Column (1) presents the number of counties for which data are available. The notation $\rho\left(4^{\text {th }}\right)$ denotes the correlation with the $4^{\text {th }}$ loan. For sources, see text. 
Table A3:

Effects of Liberty Loan Subscriptions on Commercial and Investment Banks: IV Estimates, All States vs. Restricted Sample of Idaho and its Neighbors

\begin{tabular}{|c|c|c|c|c|}
\hline & \multicolumn{2}{|c|}{ All States } & \multicolumn{2}{|c|}{$\begin{array}{c}\text { Just ID Neighbors: } \\
\text { ID vs. MT, OR, WA }\end{array}$} \\
\hline & $\begin{array}{c}\text { OLS } \\
(1)\end{array}$ & $\begin{array}{l}\text { IV } \\
(2)\end{array}$ & $\begin{array}{l}\text { OLS } \\
(3)\end{array}$ & $\begin{array}{l}\text { IV } \\
(4)\end{array}$ \\
\hline & \multicolumn{4}{|c|}{ Panel A: Ln(Commercial Bank Assets) } \\
\hline Liberty Bond 3rd $\times$ Post-1918 & $\begin{array}{c}-0.014 * * * \\
(0.002)\end{array}$ & $\begin{array}{c}-0.025^{* * *} \\
(0.004)\end{array}$ & $\begin{array}{c}-0.011 * * \\
(0.003)\end{array}$ & $\begin{array}{c}-0.037 * * * \\
(0.009)\end{array}$ \\
\hline Liberty Bond Diff $\times$ Post-1918 & $\begin{array}{c}-0.010 * * * \\
(0.002)\end{array}$ & $\begin{array}{c}-0.049 * * * \\
(0.009)\end{array}$ & $\begin{array}{l}-0.002 \\
(0.002)\end{array}$ & $\begin{array}{c}-0.067 * * * \\
(0.026)\end{array}$ \\
\hline Weak Instrument Robust Confidence Set & - & {$[-.074,-.034]$} & - & {$[-.146,-.028]$} \\
\hline County Controls, Year and County FEs & Yes & Yes & Yes & Yes \\
\hline
\end{tabular}

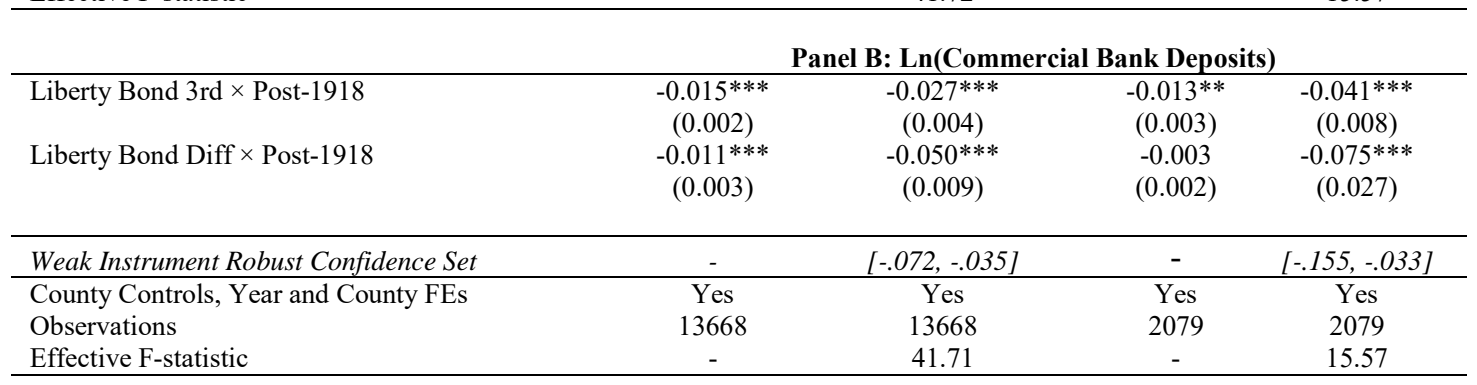

\begin{tabular}{|c|c|c|c|c|}
\hline & \multicolumn{4}{|c|}{ Panel C: Ln(\# of Investment Banks) } \\
\hline \multirow[t]{2}{*}{ Liberty Bond 3rd $\times$ Post- 1918} & $0.005 * * *$ & $0.007 * * *$ & 0.005 & $0.015 * * *$ \\
\hline & $(0.001)$ & $(0.001)$ & $(0.003)$ & $(0.005)$ \\
\hline \multirow[t]{2}{*}{ Liberty Bond Diff $\times$ Post-1918 } & 0.004 & $0.010 *$ & 0.002 & 0.026 \\
\hline & $(0.003)$ & $(0.005)$ & $(0.005)$ & $(0.020)$ \\
\hline Weak Instrument Robust Confidence Set & - & {$[.002, .021]$} & - & {$[-.002, .093]$} \\
\hline County Controls, Year and County FEs & Yes & Yes & Yes & Yes \\
\hline Observations & 6154 & 6154 & 935 & 935 \\
\hline Effective F-statistic & - & 37.86 & - & 13.03 \\
\hline
\end{tabular}

\begin{tabular}{|c|c|c|c|c|}
\hline & \multicolumn{4}{|c|}{ Panel D: 1= Investment Bank Present } \\
\hline Liberty Bond 3rd $\times$ Post-1918 & $\begin{array}{c}0.004 * * * \\
(0.001)\end{array}$ & $\begin{array}{c}0.005^{* * *} \\
(0.001)\end{array}$ & $\begin{array}{c}0.003 \\
(0.002)\end{array}$ & $\begin{array}{l}0.008^{*} \\
(0.005)\end{array}$ \\
\hline Liberty Bond Diff $\times$ Post-1918 & $\begin{array}{c}0.001 \\
(0.002)\end{array}$ & $\begin{array}{c}0.006 * * \\
(0.003)\end{array}$ & $\begin{array}{c}-0.001 \\
(0.003)\end{array}$ & $\begin{array}{c}0.013 \\
(0.017)\end{array}$ \\
\hline Weak Instrument Robust Confidence Set & - & {$[.0009 .014]$} & - & {$[-.010, .070]$} \\
\hline County Controls, Year and County FEs & Yes & Yes & Yes & Yes \\
\hline
\end{tabular}

Notes: This table presents the results of Table 5 in columns (1) and (2), and in columns (3) and (4) it presents the same regressions with the sample restricted to Idaho and its neighbor states. Idaho was the only state for which data is available that added the allotment system in the fourth loan; these regressions explore whether the comparisons between Idaho and other states presented in Table 5 are driven by regional differences in our main sample. The difference in the liberty bond participation rate between the $3^{\text {rd }}$ and $4^{\text {th }}$ loans is instrumented in the 2SLS regressions with the interaction between an indicator for whether the county first implemented the allotment system during the $4^{\text {th }}$ loan and an indicator for years after 1918 . The weak instrument robust confidence sets for the IV estimates in columns (2) and (4) reported in brackets were computed using the method proposed in Andrews (2018) and implemented in the Stata package 'twostepweakiv' using 1,000 grid points. Figure 7 presents a map of the states that used the allotment system for the third and fourth loan. The Effective F-statistics are those developed by Montiel Olea and Pfluger (2013). "County Controls" are the same time-varying controls as in Tables 4 and 5. * denotes significance at $10 \%$; ** at $5 \%$ level and $* * *$ at $1 \%$ level 